\title{
Subsurface tropical Pacific nitrogen isotopic composition of nitrate: Biogeochemical signals and their transport
}

\author{
Patrick A. Rafter, ${ }^{1,2}$ Daniel M. Sigman, ${ }^{3}$ Christopher D. Charles, ${ }^{1}$ Jan Kaiser, ${ }^{4}$ \\ and Gerald H. Haug ${ }^{5}$
}

Received 29 October 2010; revised 9 June 2011; accepted 23 October 2011; published 10 January 2012.

[1] We report measurements of the nitrogen isotopic composition of nitrate (the $\delta^{15} \mathrm{~N}$ of $\mathrm{NO}_{3}^{-}$) across the equatorial Pacific, for zonal transects from $165^{\circ} \mathrm{E}$ to $95^{\circ} \mathrm{W}$ and meridional transects across $95^{\circ}$ and $110^{\circ} \mathrm{W}$. The $\delta^{15} \mathrm{~N}$ of $\mathrm{NO}_{3}^{-}$is similar in the equatorial thermocline $(\approx 100 \mathrm{~m})$ and intermediate depth waters $(\approx 150$ to $600 \mathrm{~m})$, averaging $(7.1 \pm 0.3) \%$ and $(7.1 \pm 0.1) \%$, respectively. These values are more than $2 \%$ higher than subthermocline waters of the Southern and Atlantic Oceans and are $\approx 1 \%$ higher than putative source waters in the high latitude South Pacific (Subantarctic Mode Water, SAMW). The combined constraints of nitrate concentration and $\delta^{15} \mathrm{~N}_{\text {of }} \mathrm{NO}_{3}^{-}$in the equatorial Pacific require (1) lateral exchange between the high-latitude source waters and the zones of denitrification in the eastern tropical Pacific and (2) the accumulation of remineralized nutrients at depth. The zonal uniformity of the subsurface equatorial Pacific $\delta^{15} \mathrm{~N}$ of $\mathrm{NO}_{3}^{-}$indicates rapid transport within the equatorial zone, which works to homogenize the $\delta^{15} \mathrm{~N}$ of $\mathrm{NO}_{3}^{-}$across the Pacific basin. Against this backdrop of high $\delta^{15} \mathrm{~N}^{-}$of $\mathrm{NO}_{3}^{-}$in the tropical Pacific, we find a discrete off-equatorial core of lower $\delta^{15} \mathrm{~N}_{\text {of }} \mathrm{NO}_{3}^{-}(5.5 \pm 0.3) \%$ concentrated at $5^{\circ} \mathrm{S}$ and 150 to $200 \mathrm{~m}$ along the $110^{\circ}$ and $95^{\circ} \mathrm{W}$ transects and in apparent association with the Southern Subsurface Counter Current (SSCC). We propose that the remineralized products of nitrogen fixation, at the source of the SSCC in the western south Pacific, are the origin of the low $\delta^{15} \mathrm{~N}$ of $\mathrm{NO}_{3}^{-}$in these waters.

Citation: Rafter, P. A., D. M. Sigman, C. D. Charles, J. Kaiser, and G. H. Haug (2012), Subsurface tropical Pacific nitrogen isotopic composition of nitrate: Biogeochemical signals and their transport, Global Biogeochem. Cycles, 26, GB1003, doi:10.1029/2010GB003979.

\section{Introduction}

[2] The ${ }^{15} \mathrm{~N} /{ }^{14} \mathrm{~N}$ of nitrate is sensitive to important biogeochemical fluxes [e.g., Knapp et al., 2005] and therefore provides diagnostic constraints on nutrient budgets in the global ocean. It also provides information on the origin and history of water masses [e.g., Sigman et al., 2000], identifying processes that are not immediately evident from standard hydrographic measurements such as temperature, salinity, and nutrient concentrations. These multiple applications for the ${ }^{15} \mathrm{~N} /{ }^{14} \mathrm{~N}$ of nitrate (hereafter referred to as " ${ }^{15} \mathrm{~N}$ of $\mathrm{NO}_{3}^{-}$" where $\delta^{15} \mathrm{~N}$ is expressed relative to atmospheric $\mathrm{N}_{2}$ and equals $\mathrm{R}$ (sample)/R $\left(\mathrm{N}_{2}\right.$ of the atmosphere) - 1, with the

\footnotetext{
${ }^{1}$ Scripps Institution of Oceanography, University of California, San Diego, La Jolla, California, USA.

${ }^{2}$ Now at Department of Geosciences, Princeton University, Princeton, New Jersey, USA.

${ }^{3}$ Department of Geosciences, Princeton University, Princeton, New Jersey, USA.

${ }^{4}$ School of Environmental Sciences, University of East Anglia, Norwich, UK.

${ }^{5}$ Geological Institute, Department of Earth Science, Swiss Federal Institute of Technology, Zürich, Switzerland.

Copyright 2012 by the American Geophysical Union. 0886-6236/12/2010GB003979
}

isotope ratio $\mathrm{R}=\left[{ }^{15} \mathrm{~N}\right] /\left[{ }^{14} \mathrm{~N}\right]$ ) are being pursued in both lowand high-latitude regions of the world's oceans [Sigman et al., 2000; Voss et al., 2001; Sigman et al., 2005; DiFiore et al., 2006, 2009]. Our intention here is to highlight these various applications with a new set of $\delta^{15} \mathrm{~N}_{\text {of }} \mathrm{NO}_{3}^{-}$measurements spanning the tropical Pacific.

[3] Within the tropical Pacific, a number of biogeochemically important processes are imprinted on the $\delta^{15} \mathrm{~N}$ of $\mathrm{NO}_{3}^{-}$. For example, upwelling along the equator and on the Pacific's eastern margin delivers abundant nutrients to the surface ocean, but the entire $\mathrm{NO}_{3}^{-}$pool is not utilized (Figure 1a). This allows for ${ }^{14} \mathrm{~N}$ of $\mathrm{NO}_{3}^{-}$to be preferentially assimilated, leading to an increase in the $\delta^{15} \mathrm{~N}$ of the residual $\mathrm{NO}_{3}^{-}$in the surface ocean and producing sinking material with a lower $\delta^{15} \mathrm{~N}$ [Altabet and Francois, 1994]. As $\mathrm{NO}_{3}^{-}$consumption proceeds to completion, which occurs relatively close to the equatorial and coastal zones of upwelling, the integrated $\delta^{15} \mathrm{~N}$ of the $\mathrm{N}$ exported to depth converges on the $\delta^{15} \mathrm{~N}$ of the $\mathrm{NO}_{3}^{-}$upwelled from below.

[4] In the "oxygen-deficient zones" (ODZs) of the eastern tropical north and south Pacific (ETNP and ETSP), the bacterially mediated reduction of $\mathrm{NO}_{3}^{-}$to $\mathrm{N}_{2}$ (denitrification) leads to a deficit in $\mathrm{NO}_{3}^{-}$relative to phosphate (quantified by the stoichiometric parameter $\mathrm{N}^{*}$ [Deutsch et al., 2001]). The ODZs themselves arise from the respiration of sinking 


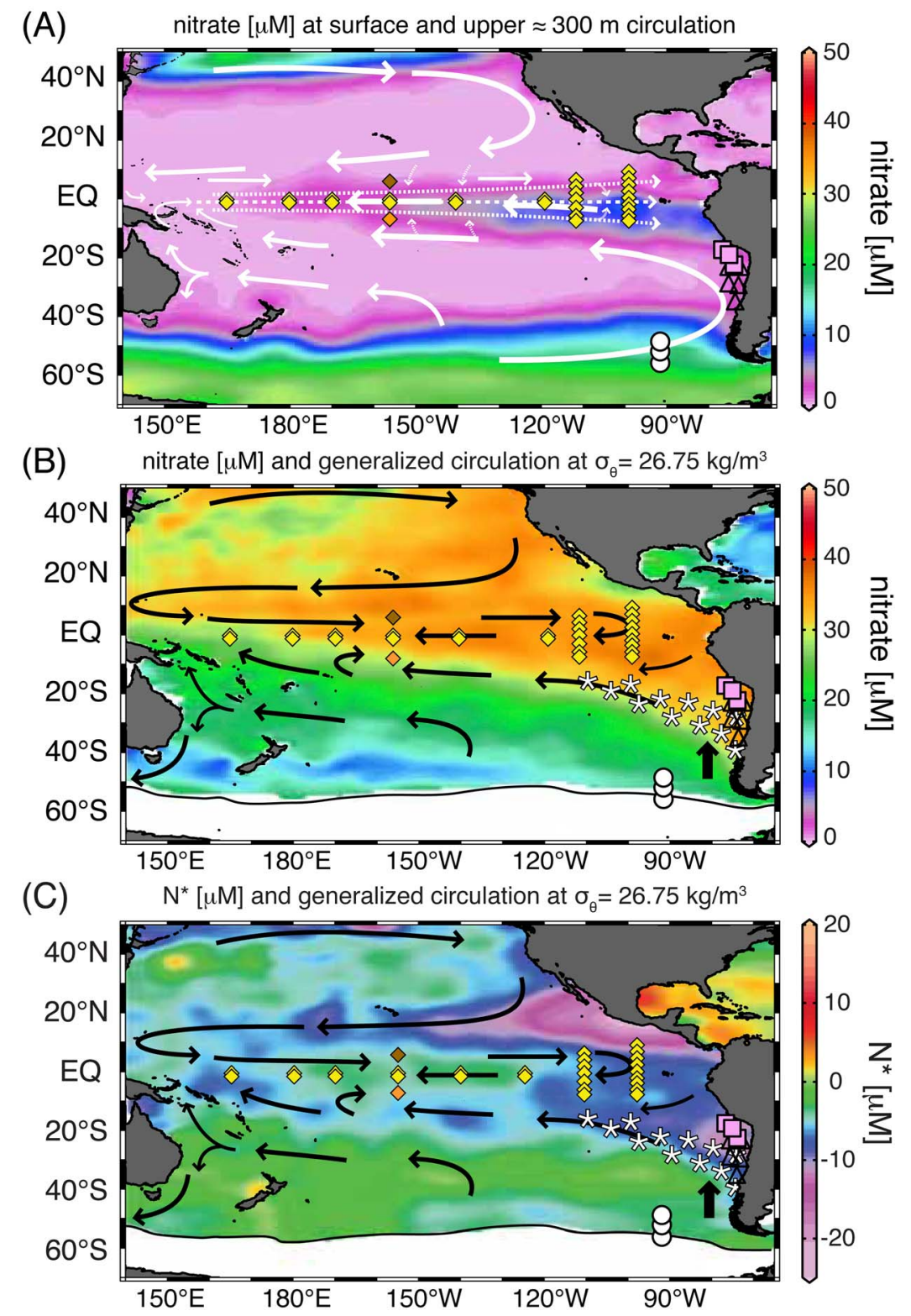

Figure 1. Maps of nitrate concentration and $\mathrm{N}^{*}$ at different depths, station locations, and generalized circulation at that depth. (a) Surface $\mathrm{NO}_{3}^{-}$concentration, (b) nitrate concentration on the 26.75 density level. And (c) nitrate deficit (" $\mathrm{N}^{*}$ "), which is at the surface in the high southern latitudes (white region) and $\approx 400 \mathrm{~m}$ in tropical Pacific [Garcia et al., 2006]. Diamonds denote measurements in this study; pink squares derive from work by Liu [1979]; black triangle values are from work by De Pol-Holz et al. [2009]; and white circles are from work by Sigman et al. [1999]. The Equatorial Under Current, and North and South Counter Currents are dashed white in Figure 1a, as are the lower branch of subtropical cell and the retroflection of the subsurface counter currents. Extra-tropical circulation (white and black arrows) is drawn from work by Reid [1997], Johnson et al. [2002], Fine et al. [1994], Ridgway and Dunn [2007], HerraizBorreguero and Rintoul [2011], and Cravatte et al. [2011]. The asterisks mark known mixing between SAMW and Chilean Margin waters [Johnson and McTaggart, 2010].

organic matter below the tropical upwelling and from the slow ventilation (delivery of oxygenated waters) of these regions, which are known as the "shadow zones" of the middepth gyre circulations (Figure 2) [Luyten et al., 1983; Codispoti and Richards, 1976; Codispoti and Packard, 1980; Codispoti and Christensen, 1985; Deutsch et al., 2001].
[5] The preferential consumption of ${ }^{14} \mathrm{NO}_{3}^{-}$by denitrification raises the $\delta^{15} \mathrm{~N}_{\text {of }} \mathrm{NO}_{3}^{-}$[Cline and Kaplan, 1975; Liu and Kaplan, 1989; Brandes et al., 1998; Voss et al., 2001; Sigman et al., 2005; Casciotti and McIlvin, 2007] producing an isotopic signal that is then transmitted through the Pacific by circulation and sinking organic matter [Sigman et al., 2009]. Therefore, the $\delta^{15} \mathrm{~N}$ of $\mathrm{NO}_{3}^{-}$tends to follow the distribution 
(A)

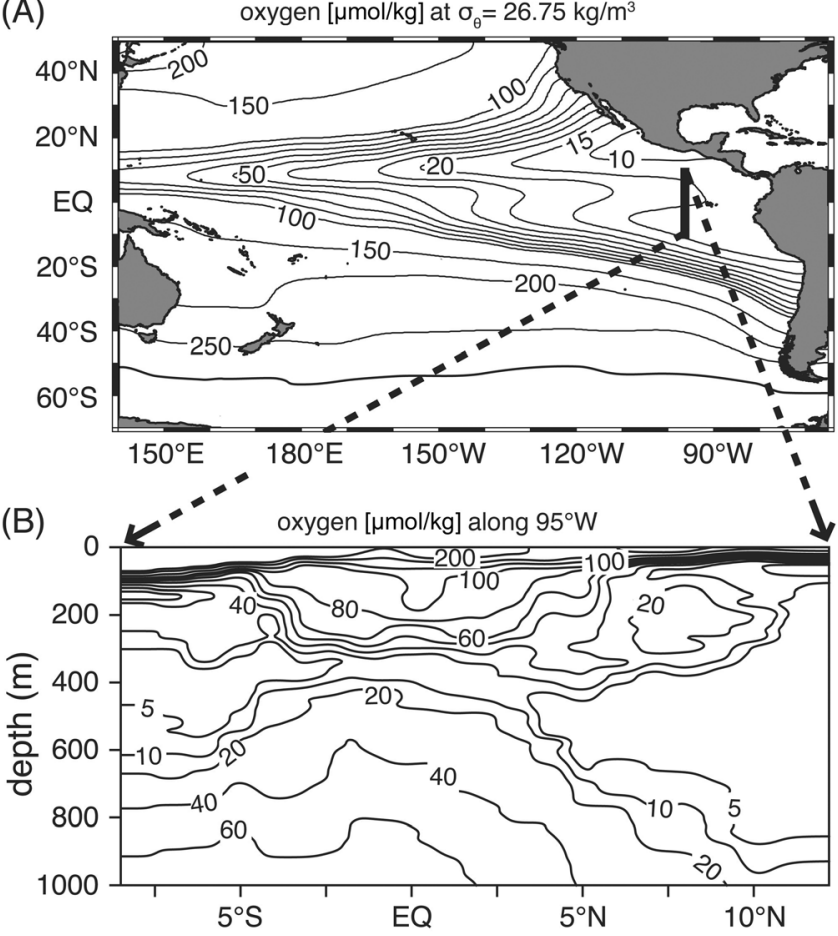

Figure 2. (a) Mean annual dissolved oxygen (in $\mu \mathrm{mol} / \mathrm{kg}$ ) on the 26.75 potential density level [Garcia et al., 2006]. This density level is $\approx 400 \mathrm{~m}$ in the tropical Pacific and is at the surface in the high southern latitudes (see contour at $\left.\approx 50^{\circ} \mathrm{S}\right)$. (b) Dissolved oxygen $(\mu \mathrm{mol} / \mathrm{kg})$ measured at hydrocast stations along the $95^{\circ} \mathrm{W}$ transect on the October/ November 2003 Ronald H. Brown cruise (transect represented by black bar in Figure 2a). Data has been interpolated from a $1 \mathrm{~m}$ depth interval with a $1^{\circ}$ latitude resolution or better. Dissolved oxygen along $110^{\circ} \mathrm{W}$ is similar to $95^{\circ} \mathrm{W}$ (Figure S1).

of other tracers for water column denitrification. Nitrate is also lost through sedimentary denitrification, which appears to be focused along the productive eastern Pacific margins [Devol and Christensen, 1993], but this process weakly influences the $\delta^{15} \mathrm{~N}$ of $\mathrm{NO}_{3}^{-}$[Brandes and Devol, 1997; Sigman et al., 2003; Lehmann et al., 2005, 2007].

[6] $\mathrm{N}$ fixation, the fixation of $\mathrm{N}_{2}$ into organic matter by a discrete set of ocean phytoplankton, is an additional influence on $\mathrm{NO}_{3}^{-}$isotopic composition, opposing the denitrification-driven loss of $\mathrm{NO}_{3}^{-}$. N fixation introduces low $\delta^{15} \mathrm{~N}$ of organic matter to the surface ocean and, upon sinking to depth, produces $\mathrm{NO}_{3}^{-}$with a low $\delta^{15} \mathrm{~N}$, as is apparent in the North Atlantic [Knapp et al., 2005, 2008] and also the IndoPacific [Brandes et al., 1998; Casciotti et al., 2008]. Because the $\delta^{15} \mathrm{~N}$ of $\mathrm{NO}_{3}^{-}$is sensitive to these transformations (discussed further below), $\mathrm{NO}_{3}^{-}$influenced by these biological processes (and the organic matter produced from this $\mathrm{NO}_{3}^{-}$) is isotopically "tagged," providing a view into the history of water masses.

[7] Here we use measurements of tropical Pacific $\delta^{15} \mathrm{~N}$ of $\mathrm{NO}_{3}^{-}$along with standard oceanographic measurements to characterize the water masses of this region based on nearsurface circulatory features and their intermediate $(>200 \mathrm{~m})$ and deep-sea $(>1000 \mathrm{~m})$ high-latitude source waters
(Figure 3). These $\delta^{15} \mathrm{~N}$ of $\mathrm{NO}_{3}^{-}$measurements are then interpreted within the context of known and concurrently measured circulation to provide additional information on the patterns of Pacific Ocean subsurface flow and their interaction with Pacific Ocean biogeochemistry. Of particular interest are the intermediate-depth South Pacific waters, which are on the same density level as the eastern tropical Pacific ODZs. It has been suggested that these intermediate waters (specifically, the Subantarctic Mode Water, SAMW) are the major source of nutrients to the equatorial Pacific thermocline [Toggweiler et al., 1991; Sarmiento et al., 2004; Palter et al., 2010], even though there is a considerable change in high to low latitude $\mathrm{NO}_{3}^{-}$characteristics (Figures $1 \mathrm{~b}$ and $1 \mathrm{c}$ ) at the density of this water mass. The $\delta^{15} \mathrm{~N}$ of $\mathrm{NO}_{3}^{-}$data reported here along with published analyses from the eastern South Pacific and Subantarctic Pacific impose significant new constraints on the subsurface pathways and apparent modification of SAMW $\mathrm{NO}_{3}^{-}$between the high and low latitude South Pacific.

[8] While understanding the distribution of nutrients is important for studies of surface ocean productivity, the complete characterization of subsurface Pacific circulation is also necessary for understanding aspects of global climate, such as the global ocean heat balance [Gordon, 1986], the upper ocean conditions that give rise to the El Niño Southern

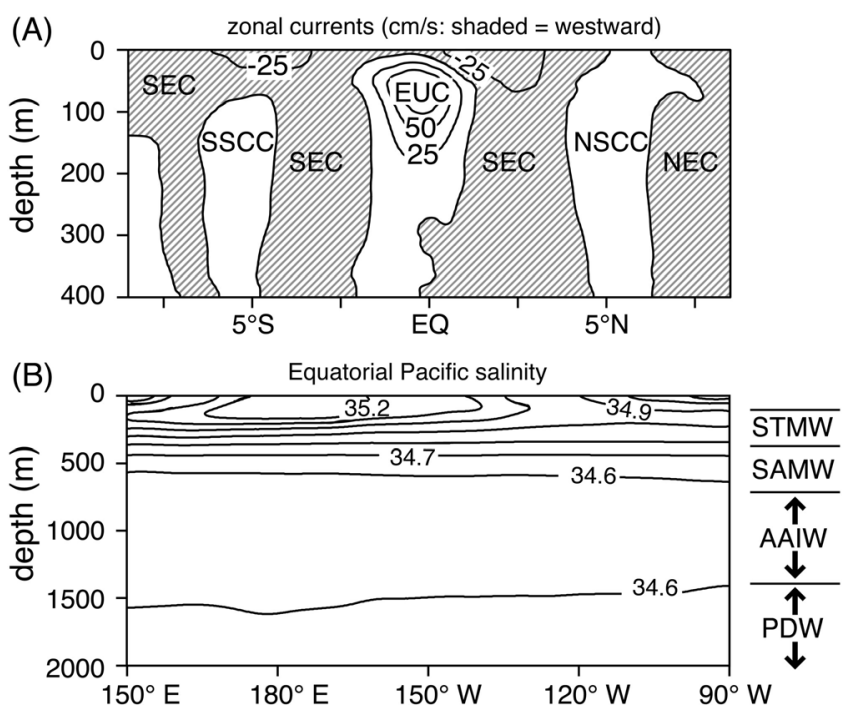

Figure 3. (a) Tropical Pacific mean annual subsurface zonal circulation $(\mathrm{cm} / \mathrm{s})$ from Johnson et al. [2002]. Shaded regions represent the westward flow of the South Equatorial Current (SEC) and the North Equatorial Current (NEC). The Equatorial Undercurrent (EUC) and the Southern and Northern Subsurface Counter Currents (SSCC and NSCC) dominate eastward circulation in the equatorial Pacific. (b) Salinity for equatorial Pacific waters [Garcia et al., 2006]. Acoustic Doppler Current Profiler (ADCP) data are used to identify water associated with the circulation of the top 200 to $400 \mathrm{~m}$. For water deeper than the ADCP measurements, water masses and their higher-latitude source (labeled on right) are identified using potential density and salinity (details in the text): Subtropical Mode Water (STMW), Subantarctic Mode Water (SAMW), Antarctic Intermediate Water (AAIW), and Pacific Deep Water (PDW). 
Oscillation [Gu and Philander, 1997], and even ice age cycling [Spero and Lea, 2002; P. A. Rafter and C. D. Charles, Pleistocene equatorial Pacific dynamics described by zonal gradients in nitrogen isotopes, submitted to Nature Geoscience, 2011]. In a more general sense, these measurements provide an essential measure of environmental conditions for regional ecological studies [e.g., Graham et al., 2007; Newsome et al., 2006] as well as sediment nitrogen isotope studies of past biogeochemical change [Farrell et al., 1995; Ganeshram et al., 1995; Robinson et al., 2009].

[9] We organize this work by first using our measurements to describe the $\mathrm{NO}_{3}^{-}$characteristics of the tropical Pacific in section 3. In this section, we also discuss the $\mathrm{NO}_{3}^{-}$properties of the Eastern Tropical South Pacific and Subantarctic Pacific observed in previous studies. In section 4, we describe some of the physical and biogeochemical processes that can explain the surface to the seafloor characteristics of equatorial Pacific $\mathrm{NO}_{3}^{-}$, and the implications of these findings are discussed in section 5. Among other results discussed here, the measurements of tropical pacific $\delta^{15} \mathrm{~N}$ of $\mathrm{NO}_{3}^{-}$demonstrate the capacity of tropical Pacific subsurface circulation to transport the geochemical signals of denitrification and nitrogen fixation westward and eastward, respectively.

\section{Materials and Methods}

[10] Tropical Pacific water samples were collected during the National Oceanic and Atmospheric Administration's (NOAA) routine maintenance of the Tropical-AtmosphereOcean (TAO) array. Collection of water by the ship's rosette was accompanied by Conductivity-Temperature-Depth (CTD) measurements and a dissolved oxygen sensor package on some occasions. Each ship has a hull-mounted Acoustic Doppler Current Profiler (ADCP), to identify direction and speed of circulatory features from $30 \mathrm{~m}$ to a maximum depth of $700 \mathrm{~m}$.

[11] Water sampling locations and depths (diamonds in Figure 1) were as established by the TAO program. In October and November of 2003, water samples were collected on board the NOAA ship RV Ronald H. Brown for meridional transects at $95^{\circ} \mathrm{W}$ and $110^{\circ} \mathrm{W}$. The zonal transects are constructed from samples retrieved on the RVs Ka'imimoana and Ronald H. Brown at $0^{\circ} \mathrm{N}$ (between $165^{\circ} \mathrm{E}$ and $125^{\circ} \mathrm{W}$ ) in fall 2004 and at $1^{\circ} \mathrm{N}$ (between $165^{\circ} \mathrm{E}$ and $95^{\circ} \mathrm{W}$ ) in late summer/fall 2005, respectively. Differences in nutrient concentrations are small between $0^{\circ} \mathrm{N}$ and $1^{\circ} \mathrm{N}$, especially below the mixed layer, but the EUC may extend over a slightly smaller depth range at $1^{\circ} \mathrm{N}$ [Firing et al., 1983; Johnson et al., 2002]. The "gyre" stations at $7^{\circ} \mathrm{N}, 155^{\circ} \mathrm{W}$ and $8^{\circ} \mathrm{S}, 155^{\circ} \mathrm{W}$ were sampled in October and December 2005, respectively.

[12] All sample bottles (60 $\mathrm{ml}$ Nalgene HDPE) were acid-washed and rinsed with DI water before shipping. At sea, sample bottles were rinsed three times with sample water, filled to a volume of $\approx 50 \mathrm{ml}$, frozen on site, and shipped overnight to laboratories at the Scripps Institution of Oceanography or Princeton University. The samples from 2003 and 2004 were analyzed for nitrate concentration $\left[\mathrm{NO}_{3}^{-}\right]$at Princeton University by reducing $\mathrm{NO}_{3}^{-}$(and nitrite, $\mathrm{NO}_{2}^{-}$, if present) to $\mathrm{NO}$ using a vanadium(III) reagent, followed by chemiluminescence measurement of NO [Braman and Hendrix, 1989]. The full suite of nutrient analyses $\left(\mathrm{NO}_{3}^{-}\right.$, nitrite, phosphate and silicate) were performed on the summer/fall 2005 water samples at the UCSB Marine Science Institute Analytical $\mathrm{Lab}$ and showed very low $(<0.1 \mu \mathrm{mol} / \mathrm{L})$ to undetectable nitrite $\left(\mathrm{NO}_{2}^{-}\right)$below the mixed layer (below the depth where temperature is $\approx 0.5^{\circ} \mathrm{C}$ different than sea surface temperature). All samples were analyzed for the ${ }^{15} \mathrm{~N} /{ }^{14} \mathrm{~N}$ ratio of $\mathrm{NO}_{3}^{-}$via the "Denitrifier Method" of Sigman et al. [2001] and Casciotti et al. [2002], with measurement error $\pm 0.3 \%$. Because the presence of nitrite could result in an underestimation of the $\delta^{15} \mathrm{~N}$ of $\mathrm{NO}_{3}^{-}$when using the Denitrifier Method [Casciotti and McIlvin, 2007], we removed $\mathrm{NO}_{2}^{-}$in potentially impacted samples using the methods of Granger et al. [2006] and Granger and Sigman [2009].

\section{Results}

\subsection{General Distribution of Tropical Pacific $\delta^{15} \mathrm{~N}$ of $\mathrm{NO}_{3}^{-}$}

[13] There is a broad depth range along the equatorial Pacific (from $\approx 150$ to at least $600 \mathrm{~m}$ ) where weighted average $\delta^{15} \mathrm{~N}$ of $\mathrm{NO}_{3}^{-}$is $(7.1 \pm 0.1) \%$ (Figure $4 \mathrm{a}$ ), more than $2 \%$ higher than comparable depths in the North Atlantic and the Antarctic [Sigman et al., 2000; DiFiore et al., 2006; Knapp et al., 2008]. While the $\delta^{15} \mathrm{~N}$ of $\mathrm{NO}_{3}^{-}$decreases below $\approx 700 \mathrm{~m}$ in the equatorial Pacific, the relative $\delta^{15} \mathrm{~N}$ elevation persists, with a $\delta^{15} \mathrm{~N}$ of $>5.5 \%$ at $3000 \mathrm{~m}$. Our stations at $7^{\circ} \mathrm{N}$ and $8^{\circ} \mathrm{S}$ and $155^{\circ} \mathrm{W}$ (Figure 4d) are essentially "upstream" of the equatorial waters [e.g., Fine et al., 1987; McCreary and Lu, 1994], and show that the subsurface $\delta^{15} \mathrm{~N}$ of $\mathrm{NO}_{3}^{-}$is $>6 \%$ down to at least $1000 \mathrm{~m}$ on both sides of the equator.

[14] For the most part, the subsurface maximum in $\delta^{15} \mathrm{~N}$ of $\mathrm{NO}_{3}^{-}$along the meridional transects $\left(110^{\circ}\right.$ and $95^{\circ} \mathrm{W}$; Figures $4 \mathrm{~b}$ and $4 \mathrm{c}$ ) occurs in the same depth range of 150 to $600 \mathrm{~m}$, but with much higher values (up to 16\%o) resulting from their proximity to the ODZs, where pelagic denitrification occurs. Indeed, the highest $\delta^{15} \mathrm{~N}$ of $\mathrm{NO}_{3}^{-}$coincides with the lowest oxygen concentrations (below $2 \mu \mathrm{mol} / \mathrm{kg}$ ) and with other tracers of ODZ processes (Figures 2 and 4 and Figure S1 in the auxiliary material) [Codispoti and Richards, 1976; Codispoti and Packard, 1980; Codispoti and Christensen, 1985; Deutsch et al., 2001]. ${ }^{1}$

[15] The elevated $\delta^{15} \mathrm{~N}$ of $\mathrm{NO}_{3}^{-}$measured throughout the tropical Pacific at $\approx 400 \mathrm{~m}$ is consistent with the deficit of $\mathrm{NO}_{3}^{-}$suggested by the $\mathrm{N}^{*}$ parameter. Assuming that $\mathrm{NO}_{3}^{-}$ uptake and regeneration follows the $16: 1$ ratio derived by Redfield [1958], measured $\mathrm{NO}_{3}^{-}$to phosphate can be normalized as "N*" (from Gruber and Sarmiento [1997] and simplified here as $\mathrm{N}^{*}=\left[\mathrm{NO}_{3}^{-}\right]-16\left[\mathrm{PO}_{4}^{3-}\right]$, where $\left[\mathrm{PO}_{4}^{3-}\right]$ is the concentration of phosphate in units of $\mu \mathrm{M}$ ). The negative $\mathrm{N}^{*}$ generated from denitrification in the eastern tropical Pacific ODZs (as well as continental margin sediments) communicates with the broader Pacific through the generalized intermediate-depth circulation (Figure 1c), resulting in negative $\mathrm{N}^{*}$ across much of the Pacific basin. The widespread distribution of negative $\mathrm{N}^{*}$ and the prevalence of elevated $\delta^{15} \mathrm{~N}$ of $\mathrm{NO}_{3}^{-}$in the equatorial Pacific at the same

\footnotetext{
${ }^{1}$ Auxiliary materials are available in the HTML. doi:10.1029/ 2010 GB003979.
} 


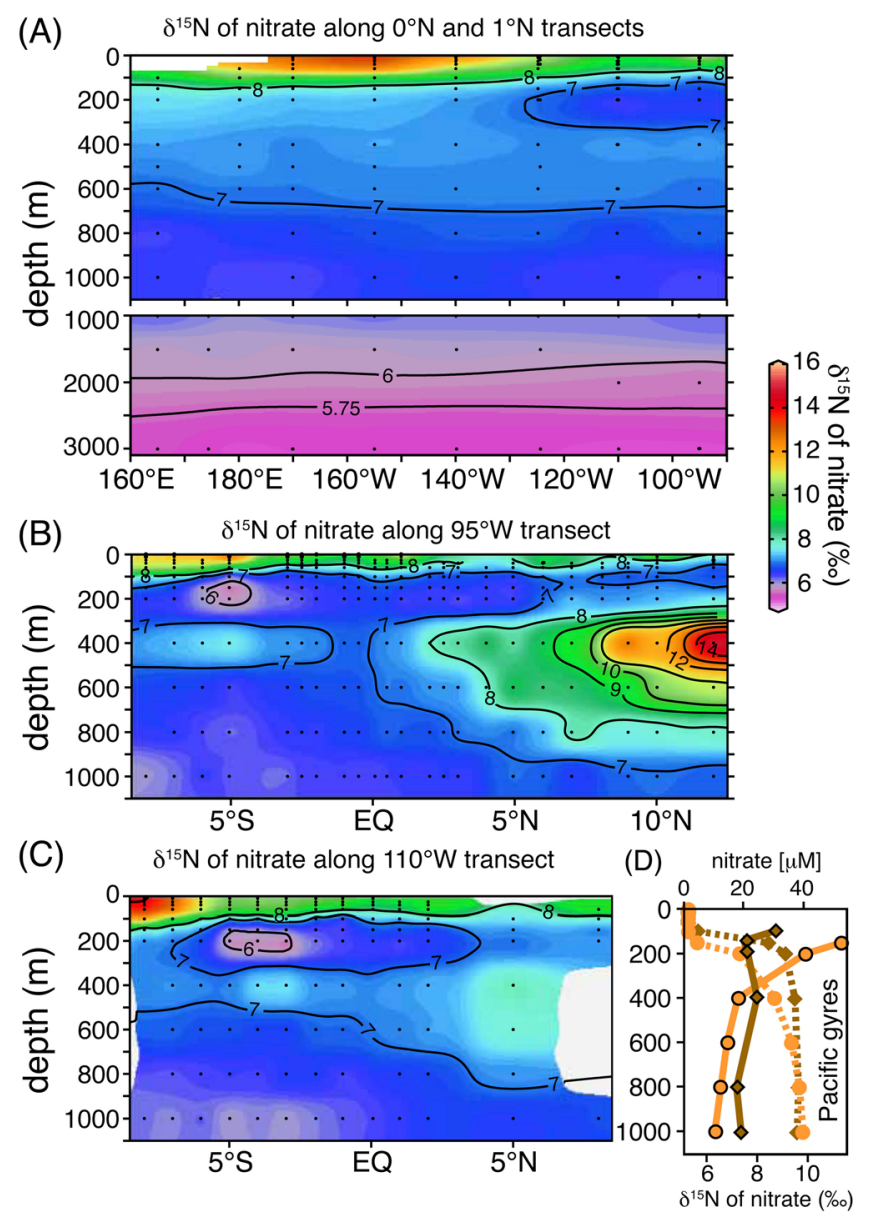

Figure 4. Measurements of the $\delta^{15} \mathrm{~N}^{\text {of }} \mathrm{NO}_{3}^{-}$(in \%) for transects along (a) $0^{\circ}$ and $1^{\circ} \mathrm{N}$ from the eastern to western equatorial Pacific, (b) $95^{\circ} \mathrm{W}$, and (c) $110^{\circ} \mathrm{W}$. We also include stations within the North and South Pacific gyres at (d) $7^{\circ} \mathrm{N}$, $155^{\circ} \mathrm{W}$ (brown) and $8^{\circ} \mathrm{S}, 155^{\circ} \mathrm{W}$ (orange), respectively. Black points indicate depth of measurement in Figures 4a, $4 \mathrm{~b}$, and $4 \mathrm{c}$. Solid lines in Figure $4 \mathrm{~d}$ are $\delta^{15} \mathrm{~N}$ of $\mathrm{NO}_{3}^{-}$, dashed are $\left[\mathrm{NO}_{3}^{-}\right]$.

depths illustrates the broad geographic scale of the influence of the denitrification process on the Pacific $\mathrm{NO}_{3}^{-}$pool.

[16] Within this large and apparently basin-wide distribution of elevated $\delta^{15} \mathrm{~N}$ of $\mathrm{NO}_{3}^{-}$, a few lower values $(6.5-6.8 \%$ ) are seen in the eastern equatorial Pacific between 150 and $200 \mathrm{~m}$ (Figures 4 and 5). This is a surprising result, in that this represents a lateral decrease in $\delta^{15} \mathrm{~N}^{\text {of }} \mathrm{NO}_{3}^{-}$toward the longitudes of the ODZs. However, the meridional transects crossing the equator at $95^{\circ} \mathrm{W}$ and $110^{\circ} \mathrm{W}$ reveal that this slightly lower eastern equatorial $\delta^{15} \mathrm{~N}^{\circ} \mathrm{NO}_{3}^{-}$is an equatorward extension of even lower $\delta^{15} \mathrm{~N}^{\circ} \mathrm{NO}_{3}^{-}(5.5 \pm 0.3) \%$ at $5^{\circ} \mathrm{S}$ and within the $100-200 \mathrm{~m}$ depth range (Figures 4 and 5). ADCP data (shading in Figure 5) shows that this low $\delta^{15} \mathrm{~N}$ of $\mathrm{NO}_{3}^{-}$water at $5^{\circ} \mathrm{S}$ appears to be associated with the Southern Subsurface Counter Current (SSCC) at both meridional transects (Figures 4 and 5). While not measured concurrently, $\mathrm{N}^{*}$ values from the World Ocean Circulation Experiment (WOCE) do not show a distinct anomaly for these waters, with respect to surrounding water masses (Figure 5c).

\subsection{Characterizing the Tropical Pacific Water Masses}

[17] The $\delta^{15} \mathrm{~N}_{\text {of }} \mathrm{NO}_{3}^{-}$measurements can be considered in the context of the broader Pacific Ocean circulation. First, we relate the $\delta^{15} \mathrm{~N}_{\text {of }} \mathrm{NO}_{3}^{-}$(and other parameters) to the nearsurface currents (upper 200 to $300 \mathrm{~m}$ ) using concurrent and historical ADCP data based on the work of Johnson et al. [2002] (Figures 3 and 5 and Table 1).

[18] We define the Equatorial Under Current (EUC) as all eastward-flowing water at thermocline depth (dashed line on equator in Figure 1a) at a depth of $\approx 75 \mathrm{~m}$ in the east and $150 \mathrm{~m}$ in the west and within $1^{\circ}$ of the equator. The weighted average $\delta^{15} \mathrm{~N}$ of $\mathrm{NO}_{3}^{-}$for the EUC is $(7.1 \pm 0.3) \%$ (averaged below the depths where algal $\mathrm{NO}_{3}^{-}$assimilation increases the $\delta^{15} \mathrm{~N}$ of $\mathrm{NO}_{3}^{-}$). The other eastward subsurface jets-the Northern and Southern Subsurface Counter Currents (NSCC and SSCC) - are identified as eastward flow at their climatological positions (dotted lines in Figure 1a; from $\approx 4^{\circ}$ to $6^{\circ} \mathrm{N}$ and $4^{\circ}$ to $6^{\circ} \mathrm{S}$ and $100-300 \mathrm{~m}$ depth east to west), in which the $\delta^{15} \mathrm{~N}$ of $\mathrm{NO}_{3}^{-}$averages $(6.8 \pm 0.4) \%$ and $(5.5 \pm 0.3) \%$, respectively. The waters upwelled at the equatorial Pacific surface - the EUC - are ultimately ventilated by Subtropical Mode Water (STMW), which is carried within the subtropical gyres of the North and South Pacific [e.g., Tsuchiya et al., 1989; Fine et al., 1987] within the potential density range of 25.0 to $\approx 26.5$ (roughly 50 to $200 \mathrm{~m}$ depth along the equator). Our stations at $7^{\circ} \mathrm{N}$ and $8^{\circ} \mathrm{S}, 155^{\circ} \mathrm{W}$ are within the currents that essentially feed the EUC (the NEC and SEC, respectively). The $7^{\circ} \mathrm{N}$ station (NEC) $\delta^{15} \mathrm{~N}$ of $\mathrm{NO}_{3}^{-}$averages $(7.5 \pm 0.1) \%$ o $(n=2)$, but there are no samples within this depth range for the $8^{\circ} \mathrm{S}$ (SEC) station.

[19] Deeper waters along the equator are characterized on the basis of potential density and salinity in order to identify their source (labeled to the right of Figure 3b). The intermediate-depth equatorial Pacific waters are primarily ventilated in the South Pacific [Fine et al., 1994] and are labeled for their respective ventilation sources, such as "EqPac(SAMW)," which is ventilated by Subantarctic Mode Water along the 26.5 to 27.1 isopycnals (approximately 200 to $600 \mathrm{~m}$ at the equator). Likewise, "EqPac(AAIW)" is a salinity minimum water below $\mathrm{EqPac}(\mathrm{SAMW})$ that is ventilated by Antarctic Intermediate Water [Hanawa and Talley, 2001; Sloyan et al., 2003]. We do not include the North Pacific Intermediate Water (NPIW) as a source for intermediate equatorial waters because of its limited input to equatorial waters at densities deeper than 26.5 [e.g., Fine et al., 1994]. More recent work also affirms the dominance of the south Pacific on water mass tracers at intermediate depths [Bostock et al., 2010]. However, NPIW most likely contributes to intermediate waters at the North Pacific subtropical gyre station $\left(7^{\circ} \mathrm{N}, 155^{\circ} \mathrm{W}\right)$, which averages $(7.8 \pm$ $0.3) \%$ between 26.5 to 27.1 potential density (Figure 1a). At these depths, the SEC station $\left(8^{\circ} \mathrm{S}, 155^{\circ} \mathrm{W}\right)$ is ventilated by SAMW, and $\delta^{15} \mathrm{~N}$ of $\mathrm{NO}_{3}^{-}$averages $(7.3 \pm 0.5) \%$ (Table 1$)$. From 1500 to 3000 m, Pacific Deep Water (PDW) is a mixture of North Atlantic Deep Water, Upper and Lower Circumpolar Deep Waters.

\subsection{Characterizing the High Latitude and ODZ Waters of the South Pacific}

[20] To allow for a direct comparison between EqPac(SAMW) (defined above) and SAMW, we compile 

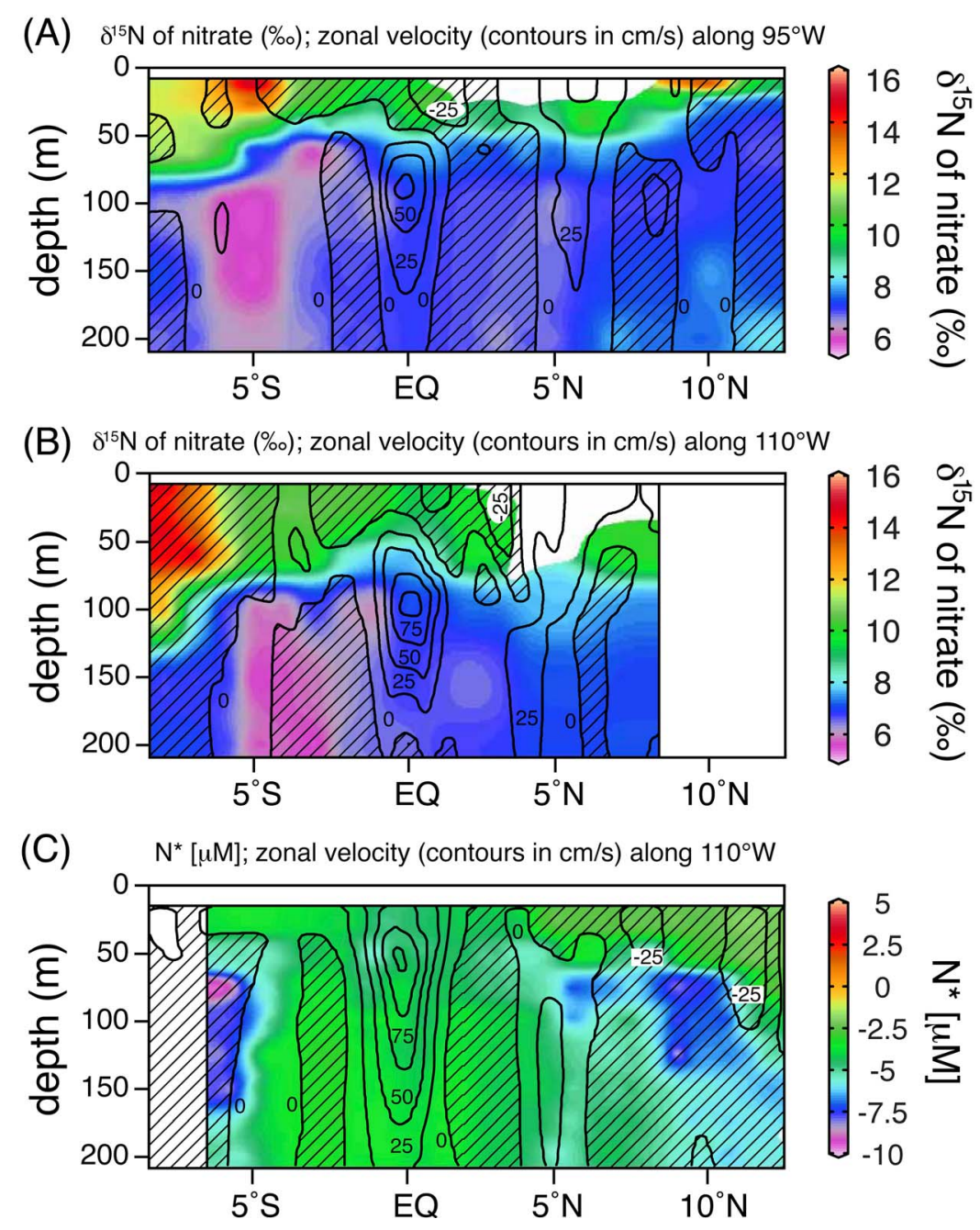

Figure 5. Measurements of the $\delta^{15} \mathrm{~N}$ of $\mathrm{NO}_{3}^{-}$(in \%o) for the (a) $95^{\circ} \mathrm{W}$ transect, (b) $110^{\circ} \mathrm{W}$ transect from Figure 4, along with (c) a transect of $\mathrm{N}^{*}$ along $110^{\circ} \mathrm{W}$ from World Ocean Circulation Experiment (WOCE) (see color bar on right for values). Black contours correspond to zonal current velocity to $210 \mathrm{~m}$ from Acoustic Doppler Current Profiler (ADCP). Shaded contours represent westward circulation in $\mathrm{cm} / \mathrm{s}$. Note the lowest $\delta^{15} \mathrm{~N}$ of $\mathrm{NO}_{3}^{-}$values are found for 100 and $150 \mathrm{~m}$ depth at $\approx 5^{\circ} \mathrm{S}$. White boxes denote regions of no data.

average values for SAMW and AAIW from the Southern Ocean (white circles in Figure 1) in Table 2 [Sigman et al., 2000; DiFiore et al., 2006]. Recent work using ARGO autonomous profiling floats illustrates that only SAMW formed in the southeast Pacific reaches the lower latitudes, with SAMW from the central Pacific remaining within the gyre circulation [Herraiz-Borreguero and Rintoul, 2011]. Therefore, we use measurements from the southeast Pacific for our estimates [Sigman et al., 2000]. To capture the characteristics of the newly formed SAMW, we average measurements made within $5^{\circ}$ latitude north of the Subantarctic Front and within the $26.5-27.1 \mathrm{~kg} / \mathrm{m}^{3}$ potential density range (as defined by Hanawa and Talley [2001]) and excluded mixed layer data (where $\delta^{15} \mathrm{~N}$ of $\mathrm{NO}_{3}^{-}$is seasonally elevated by summertime $\mathrm{NO}_{3}^{-}$assimilation). The mean $\delta^{15} \mathrm{~N}$ of $\mathrm{NO}_{3}^{-}$ of SAMW (SE Pacific) is $(6.3 \pm 0.2) \%$ (Table 2$)$, an elevation of $\approx 1 \%$ above subsurface Antarctic zone water, which results from the incorporation of $\mathrm{NO}_{3}^{-}$that has been partially consumed by phytoplankton assimilation in
Southern Ocean surface waters [Sigman et al., 1999; 2000] and presumably also some admixture of lower latitude thermocline waters influenced by denitrification. AAIW is defined as salinity minimum water $(\mathrm{S}<34.5)$ below SAMW and has a potential density between 27.1 and 27.3 [Hanawa and Talley, 2001].

[21] In addition to these high southern latitude water masses, we estimate representative values from ETSP ODZ (pink squares in Figure 1). The ETSP values (from the Peruvian and Chilean Margins [Liu, 1979; De Pol Holz et al., 2009]) are averages of low oxygen waters with $\mathrm{N}^{*}$ less than $-15 \mu \mathrm{M}$ (by the definition used here) and within the density range of SAMW.

\subsection{South Pacific-Equatorial Pacific Connections at Intermediate Depths}

[22] We compare the nitrate-related characteristics of the equatorial Pacific (both averaged along the equator and at $\left.8^{\circ} \mathrm{S}, 155^{\circ} \mathrm{W}\right)$, Subantarctic, and Eastern Tropical South 
Table 1. Average Values of Select Parameters for Water Masses in the Equatorial Pacific

\begin{tabular}{|c|c|c|c|c|c|c|c|c|c|c|}
\hline $\begin{array}{l}\text { Water Mass }^{\mathrm{a}} \\
\text { (Density Range) }\end{array}$ & $\begin{array}{c}\text { Depth } \\
\text { Range } \\
(\mathrm{m})\end{array}$ & Value $^{\mathrm{b}}$ & $\begin{array}{l}\text { Nitrate } \\
(\mu \mathrm{M})\end{array}$ & $\begin{array}{c}\delta^{15} \mathrm{~N} \\
\text { of } \mathrm{NO}_{3}^{-} \\
(\% 0)\end{array}$ & $\begin{array}{c}\mathrm{N}^{*} \\
(\mu \mathrm{M})\end{array}$ & $\begin{array}{l}\text { Theta } \\
\left({ }^{\circ} \mathrm{C}\right)\end{array}$ & Salinity & $\begin{array}{l}\text { Dissolved } \\
\text { Oxygen }^{c} \\
(\mu \mathrm{mol} / \mathrm{kg})\end{array}$ & $\begin{array}{l}\text { Potential } \\
\text { Density } \\
\qquad(\sigma \theta)\end{array}$ & $\begin{array}{c}\text { Eastward } \\
\text { Velocity } \\
(\mathrm{cm} / \mathrm{s})\end{array}$ \\
\hline \multicolumn{11}{|c|}{ Equatorial Pacific } \\
\hline \multirow[t]{2}{*}{ EUC $(\approx 26.0)$} & $100-150$ & Av. & 14.0 & 7.1 & $(-5.1)^{\mathrm{d}}$ & 16.33 & 34.99 & 126.9 & 25.6 & 47.9 \\
\hline & & $\mathrm{SD}$ & 6.5 & 0.3 & $(0.9)$ & 2.6 & 0.12 & $\mathrm{na}^{\mathrm{e}}$ & 0.6 & 26.4 \\
\hline \multirow[t]{2}{*}{$\mathrm{EqPac}(\mathrm{SAMW})(26.5-27.1)$} & $300-600$ & Av. & 33.5 & 7.1 & $(-5.2)$ & 8.2 & 34.64 & 34.8 & 26.9 & 0.2 \\
\hline & & $\mathrm{SD}$ & 3.7 & 0.1 & $(1.3)$ & 1.2 & 0.06 & 0.8 & 0.1 & 11.4 \\
\hline \multirow[t]{2}{*}{ EqPac(AAIW) (27.1-27.3) } & $600-1500$ & Av. & 40.1 & 6.8 & $(-5.7)$ & 5.7 & 34.56 & 85.0 & 27.2 & na \\
\hline & & SD. & 1.7 & 0.3 & $(1.3)$ & 1.0 & 0.02 & 5.0 & 0.1 & na \\
\hline \multirow[t]{2}{*}{ Equatorial Pacific PDW (27.3+) } & $1500-3000$ & Av. & 39.4 & 5.8 & $(-4.9)$ & 2.0 & 34.65 & 115 & 27.7 & na \\
\hline & & $\mathrm{SD}$ & 1.1 & 0.5 & $(1.1)$ & 0.9 & 0.04 & 5.2 & 0.1 & na \\
\hline \multirow[t]{2}{*}{$\mathrm{NSCC}$} & $100-200$ & Av. & 29.8 & 6.9 & na & 15.2 & 34.81 & 60.3 & 25.7 & 19.4 \\
\hline & & $\mathrm{SD}$ & 3.9 & 0.6 & na & 3.8 & 0.12 & 41.5 & 0.9 & 5.4 \\
\hline \multirow[t]{2}{*}{$\mathrm{SSCC}$} & $100-200$ & Av. & 25.7 & 5.5 & na & 14.5 & 35.03 & 40.4 & 26.1 & 17.9 \\
\hline & & SD. & 8.9 & 0.3 & na & 2.3 & 0.14 & 41.2 & 0.4 & 10.1 \\
\hline \multicolumn{11}{|c|}{ Off-Equatorial (Gyre Waters) } \\
\hline \multirow[t]{2}{*}{$8^{\circ} \mathrm{S}, 155^{\circ} \mathrm{W}(26.5-27.1)$} & $400-600$ & Av. & 32.4 & 7.3 & $(-4.7)$ & 8.0 & 34.61 & na & 26.97 & na \\
\hline & & SD & 3.0 & 0.5 & 1.0 & 1.2 & 0.06 & na & 0.13 & na \\
\hline \multirow[t]{2}{*}{$7^{\circ} \mathrm{N}, 155^{\circ} \mathrm{W}(26.5-27.1)$} & $300-600$ & Av. & 35.9 & 7.7 & $(-6.4)$ & 8.7 & 34.63 & na & 26.96 & na \\
\hline & & $\mathrm{SD}$ & 2.2 & 0.3 & 1.0 & 1.2 & 0.05 & na & 0.11 & na \\
\hline
\end{tabular}

${ }^{a}$ The Equatorial Under Current (EUC) and Northern and Southern Subsurface Counter Currents (NSCC and SSCC) were identified using climatological locations and concurrent ADCP data. The intermediate and deeper water masses (potential density $>26.5$ ) were identified based on potential density and salinity characteristics of their putative South Pacific source waters seen in Figure 3 (Subantarctic Mode Water and Antarctic Intermediate Water: SAMW and AAIW).

"Average values found in the "Av." row and standard deviation in the row labeled "SD."

${ }^{\mathrm{c}}$ Dissolved oxygen was not measured at all longitudes.

${ }^{\mathrm{d}}$ Values in parentheses are from World Ocean Atlas 2005 [Garcia et al., 2006].

${ }^{\mathrm{e}}$ Measurements not available.

Pacific waters in Figure $6\left(\delta^{15} \mathrm{~N}\right.$ of $\mathrm{NO}_{3}^{-},\left[\mathrm{NO}_{3}^{-}\right]$, and $\mathrm{N}^{*}$; all within the density range of 26.5 to 27.1$)$. As is expected from Figures $1 \mathrm{~b}$ and $1 \mathrm{c}$, the nitrate concentration and $\mathrm{N}^{*}$ of SAMW are considerably different than the equatorial Pacific in this density range, and the $\delta^{15} \mathrm{~N}$ of $\mathrm{NO}_{3}^{-}$adds an additional constraint: EqPac(SAMW) is $\approx 1 \%$ higher than SAMW (Figure 6). Furthermore, the south Pacific subtropical gyre $\delta^{15} \mathrm{~N}$ of $\mathrm{NO}_{3}^{-}$(SEC) is essentially the same as the equatorial Pacific, indicating that the modification of SAMW-derived waters takes place before arrival at the equator. These few SEC measurements are important here because the same depth and density north of the equator (at our NEC station) are similarly elevated in $\delta^{15} \mathrm{~N}$ of $\mathrm{NO}_{3}^{-}$(Figure $4 \mathrm{~d}$ ) and negative in $\mathrm{N}^{*}$. Without the SEC measurements, it could be argued that a major component of the equatorial Pacific $\mathrm{NO}_{3}^{-}$ pool at these depths $(\approx 200$ to $600 \mathrm{~m}$ ) is derived from the NEC, but our data are consistent with a primarily South Pacific origin [Fine et al., 1994]. The differences between high and low latitude waters of this density range also extend to temperature and salinity, with the lower latitude waters being warmer and more saline (Figure S2).

[23] In order to understand how equatorial Pacific $\mathrm{NO}_{3}^{-}$ acquires these characteristics, one approach is to consider the processes by which SAMW may be modified into the $\mathrm{NO}_{3}^{-}$ characteristics of the equatorial Pacific subsurface. Simple calculations can account for the three processes by which SAMW can be modified to generate the properties of equatorial Pacific waters of similar density: lateral exchange

Table 2. Average Values of Select Parameters for Subantarctic Mode Water (SAMW), Antarctic Intermediate Water (AAIW), and the Oxygen Deficient Zone of the Eastern Tropical South Pacific $\left(\mathrm{N}^{*}<-15\right)$

\begin{tabular}{|c|c|c|c|c|c|c|c|c|}
\hline $\begin{array}{c}\text { Water Mass }{ }^{\mathrm{a}} \\
\text { (Density Range) }\end{array}$ & Value $^{\mathrm{b}}$ & $\begin{array}{c}\text { Nitrate } \\
(\mu \mathrm{M})\end{array}$ & $\begin{array}{c}\delta^{15} \mathrm{~N} \text { of } \mathrm{NO}_{3}^{-} \\
(\% \mathrm{o})\end{array}$ & $\begin{array}{c}\mathrm{N}^{*} \\
(\mu \mathrm{M})\end{array}$ & $\begin{array}{l}\text { Theta } \\
\left({ }^{\circ} \mathrm{C}\right)\end{array}$ & Salinity & $\begin{array}{l}\text { Dissolved Oxygen } \\
(\mu \mathrm{mol} / \mathrm{kg})\end{array}$ & $\begin{array}{l}\text { Potential Density } \\
\left(\mathrm{kg} / \mathrm{m}^{3}\right)\end{array}$ \\
\hline \multicolumn{9}{|c|}{ High Latitude Source Waters } \\
\hline \multirow[t]{2}{*}{ SE Pacific SAMW (26.5-27.1) } & Av. & 21.7 & 6.3 & $(-3.1)^{\mathrm{c}}$ & 5.5 & 34.02 & 144.6 & 27.0 \\
\hline & $\mathrm{SD}$ & 2.2 & 0.2 & $(0.6)$ & 0.3 & 0.03 & 5.4 & 0.05 \\
\hline \multirow[t]{2}{*}{ SE PacificAAIW (27.1-27.3) } & Av. & 30.0 & 5.8 & -2.9 & 4.4 & 34.40 & 210.6 & 27.2 \\
\hline & $\mathrm{SD}$ & 4.2 & 0.3 & 0.6 & 1.5 & 0.1 & 21.6 & 0.2 \\
\hline \multicolumn{9}{|c|}{ Oxygen Deficient Zones ${ }^{\mathrm{d}}$} \\
\hline \multirow[t]{2}{*}{ ETSP ODZ (26.5-27.1) } & Av. & 26.6 & 12.0 & -19.1 & 10.9 & 34.74 & $\mathrm{na}^{\mathrm{e}}$ & 26.6 \\
\hline & $\mathrm{SD}$ & 3.5 & 1.7 & 3.0 & 0.6 & 0.10 & na & 0.1 \\
\hline
\end{tabular}

${ }^{\mathrm{a}}$ Values for SAMW and AAIW are from Sigman et al. [2000]. Eastern Tropical South Pacific Oxygen Deficient Zone (ETSP ODZ) values are from Liu [1979] and De Pol Holz et al. [2009].

bAverage values found in the "Av." row and standard deviation in the row labeled "SD."

${ }^{c}$ Values in parentheses are from World Ocean Atlas 2005 [Garcia et al., 2006].

${ }^{\mathrm{d}}$ The Oxygen Deficient Zone values were averaged for measurements between potential density $(\sigma \theta)$ range $=26.5$ and 27.1 and for $\mathrm{N}^{*}<-15$.

${ }^{\mathrm{e}}$ Measurements not available. 


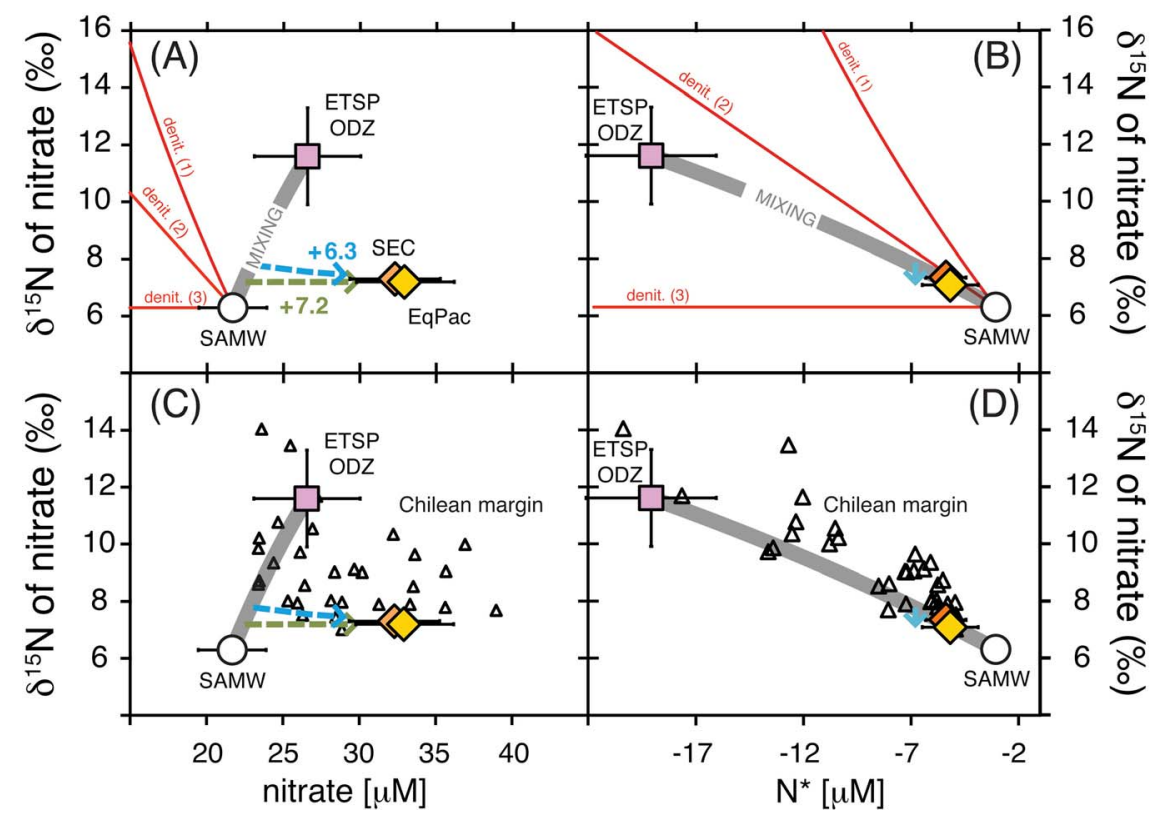

Figure 6. (a-d) Average $\left[\mathrm{NO}_{3}^{-}\right], \mathrm{N}^{*}$ and $\delta^{15} \mathrm{~N}$ of $\mathrm{NO}_{3}^{-}$in the density range of 26.5 to 27.1 for the southeast Pacific SAMW (white circle), the Eastern Tropical South Pacific Oxygen Deficient Zones (ETSP ODZ: pink square), the South Equatorial Current (SEC: orange diamond), and the equatorial Pacific (EqPac: yellow diamond). End-member values and references are in Tables 1 and 2. In Figures 6a and 6b, the trajectory of SAMW upon denitrification (red lines) is shown for an isotope effect of 25, 12.5, and 0\% $(1,2$, and 3). Mixing trajectories (gray lines) between SAMW and the ETSP are also shown. We also demonstrate the modification of the mixed water mass by adding remineralized $\mathrm{NO}_{3}^{-}$with different isotopic composition (dashed green and dashed blue arrows for $\mathrm{N}$ remineralization equal to $+7.2 \%$ and $+6.3 \%$ o respectively). These calculations assume $\mathrm{NO}_{3}^{-}$to phosphate remineralization of 16:1. Measurements from the Chilean Margin (a likely region of mixing between SAMW and ODZ) are included in Figures 6c and 6d as black triangles [De Pol-Holz et al., 2009]. N* values for the Chilean Margin are climatological from Garcia et al. [2006]. Error bars represent 1 standard deviation for average values.

("mixing"), the addition of $\mathrm{NO}_{3}^{-}$through remineralization of organic matter, and denitrification.

[24] Our first approach focuses on the $\left[\mathrm{NO}_{3}^{-}\right], \delta^{15} \mathrm{~N}$ of $\mathrm{NO}_{3}^{-}$, and $\mathrm{N}^{*}$ for mixing between SAMW and the region of denitrification in the ETSP ODZ (gray lines in Figure 6). The simplest formulation of this process is given by the equation

$$
\delta_{\mathrm{mix}} C_{\mathrm{mix}}=\delta_{a} C_{a} X_{a}+\delta_{b} C_{b}\left(1-X_{a}\right)
$$

where subscript "mix" indicates the values for the mixed product, the subscripts " $a$ " and " $b$ " indicate the values for the mixing end-members, " $\mathrm{X}_{\mathrm{a}}$ " is the proportion of water mass mixing of end-member " $\mathrm{a}$ " in the mixture, "C" is the nitrate concentration. This end-member mixing calculation is narrowly focused on explaining the equatorial Pacific characteristics, given these two end-members; the origin of the characteristics of these end-members is not addressed here.

[25] Lateral exchange between these water masses (broad gray lines) produces a convex curve in Figure 6 because the mixture $\delta^{15} \mathrm{~N}$ of $\mathrm{NO}_{3}^{-}$is biased toward the mixing endmember with higher $\left[\mathrm{NO}_{3}^{-}\right]$(the ETSP ODZ). As can be seen in Figures $6 \mathrm{a}$ and $6 \mathrm{~b}$, this simple mixing scheme between SAMW and the ETSP ODZ can produce the same $\delta^{15} \mathrm{~N}$ of $\mathrm{NO}_{3}^{-}$and $\mathrm{N}^{*}$ of the equatorial Pacific intermediate waters, but it cannot explain the higher equatorial Pacific $\left[\mathrm{NO}_{3}^{-}\right]$ (Figure 6a).
[26] The second approach is to simulate the addition of remineralized nutrients while assuming a regenerated nitrate: phosphate $=16$ and no isotopic fractionation during remineralization. This is demonstrated in Figure 6 for a $\delta^{15} \mathrm{~N}$ of $\mathrm{NO}_{3}^{-}$addition of $6.3 \%$ (dashed blue arrow) and 7.1\%o (dashed green arrow) based on SAMW and EqPac(SAMW) values. The starting point along the mixing line was chosen to produce a final $\delta^{15} \mathrm{~N}_{\text {of }} \mathrm{NO}_{3}^{-}$equal to the EqPac(SAMW). In this scheme, it is apparent that two processes working in tandem-mixing with the ETSP ODZ and the addition of remineralized nitrate - can modify SAMW to match the equatorial Pacific waters (both along the equator and at $8^{\circ} \mathrm{S}$, $155^{\circ} \mathrm{W}$ ) of similar density. The arrow representing $7.1 \%$ in Figures $6 \mathrm{~b}$ and $6 \mathrm{~d}$ is not seen because, with the assumption of regenerated nitrate to phosphate ratio equaling 16:1, there is no change in $\mathrm{N}^{*}$ or $\delta^{15} \mathrm{~N}$ of $\mathrm{NO}_{3}^{-}$. The arrow representing the addition of $6.3 \%$ nitrate is slightly to the left of the EqPac(SAMW) marker in Figures 6c and 6d. Variations in the nutrient uptake and regenerated nitrate to phosphate ratio (as have been suggested by Mills and Arrigo [2010]) would alter the $\mathrm{N}^{*}$ of the "regenerated nitrate" addition, angling the arrows toward the left in Figures $6 \mathrm{c}$ and $6 \mathrm{~d}$ in the case of regenerated $\mathrm{N}$ : $\mathrm{P}$ ratio lower than 16 . If so, this might require a change in the assumption of the mean $\delta^{15} \mathrm{~N}$ of the remineralized $\mathrm{NO}_{3}^{-}$and / or the proportions of the end-members in the water mass mixing calculation. 
[27] We also provide the approximate trajectories in the nitrate characteristics of SAMW-derived water were it to undergo denitrification (red lines). Three different sets of assumptions are shown: a Rayleigh model (closed-system) assuming a denitrification isotope effect $(\varepsilon)$ of $-25 \%$ (equation (1)) [Brandes et al., 1998; Sigman et al., 2003]; a steady state model (open system) with a much smaller isotope effect of $-12.5 \%$ (equation (2)); and a final calculation using a $0 \%$ isotope effect (equation (3)) meant to represent sedimentary denitrification. The equations are the Rayleigh fractionation,

$$
\ln \left(1+\delta_{\text {substrate }}\right)=\ln \left(1+\delta_{\text {initial }}\right)+\varepsilon \ln f,
$$

and the Steady State fractionation,

$$
\left(1+\delta_{\text {substrate }}\right)=\left(1+\delta_{\text {initial }}\right)-\varepsilon(1-f),
$$

where " $\mathrm{f}$ " is the fraction of $\mathrm{NO}_{3}^{-}$remaining and " $\varepsilon$ " is the isotope effect, defined here as ${ }^{15} \mathrm{k} /{ }^{14} \mathrm{k}-1\left({ }^{15} \mathrm{k}\right.$ and ${ }^{14} \mathrm{k}$ are the rate coefficients for the reactions of $\mathrm{NO}_{3}^{-}$with ${ }^{15} \mathrm{~N}$ and $\mathrm{NO}_{3}^{-}$ with ${ }^{14} \mathrm{~N}$, respectively). For calculating changes to $\mathrm{NO}_{3}^{-}$and phosphate concentrations during denitrification, we assume that for every 104 moles of $\mathrm{NO}_{3}^{-}$respired, $1 \mathrm{~mol}$ of phosphate is regenerated [Anderson, 1995]. In the sedimentary denitrification model - denit. (3) - there is no change to $\delta^{15} \mathrm{~N}$ of $\mathrm{NO}_{3}^{-}$in this water mass (because all $\mathrm{NO}_{3}^{-}$is consumed during denitrification), but $\left[\mathrm{NO}_{3}^{-}\right]$and $\mathrm{N}^{*}$ decrease [Brandes and Devol, 2002].

[28] It is readily apparent that none of the models of "denitrified" SAMW match the equatorial Pacific waters at similar density range, especially with respect to $\left[\mathrm{NO}_{3}^{-}\right]$ because these denitrification models reduce the already low SAMW values (Figure 6).

\section{Discussion}

[29] The $\mathrm{NO}_{3}^{-}$characteristics of the tropical Pacific (elevated $\delta^{15} \mathrm{~N}$ of $\mathrm{NO}_{3}^{-}$and negative $\mathrm{N}^{*}$ ) demand some degree of mixing between this well-oxygenated region and the Oxygen Deficient Zones of the eastern tropical Pacific. Balancing this constraint with the additional requirement of nutrient sources associated with Subantarctic Mode Water [Toggweiler et al., 1991; Sarmiento et al., 2004; Palter et al., 2010] requires the admixture of water with higher $\delta^{15} \mathrm{~N}$ of $\mathrm{NO}_{3}^{-}$and more negative $\mathrm{N}^{*}$ (Figures 1 and 6). Below, we propose where and how SAMW-derived waters are modified and how these waters influence the equatorial Pacific thermocline. This proposal is followed by a more general consideration of the nitrate properties of the entire equatorial Pacific waters (from the EUC to the abyss).

\subsection{Modifying SAMW Nitrate}

[30] Our simple calculations (Figure 6) illustrate that mixing between SAMW and the ETSP ODZ along with the addition of remineralized nutrients can explain the apparent change in SAMW nitrate characteristics between the high and low latitude waters (see Figures $1 \mathrm{~b}$ and 1c). While additional observations would help delineate the regional expression of these processes, the station within the South Pacific subtropical gyre $\left(8^{\circ} \mathrm{S}, 155^{\circ} \mathrm{W}\right)$ indicates that the modification of SAMW occurs before these waters reach the equator, confining this alteration to the extra-tropical South
Pacific. In fact, recent observations confirm the Chilean Margin as a region where SAMW mixes with the warm, salty, oxygen-poor waters of the eastern tropical Pacific [Johnson and McTaggart, 2010]. This eddy-diffusive mixing takes place in the southeast Pacific along the boundary between the lower nitrate / higher $\mathrm{N}^{*} \mathrm{SAMW}$ and the higher nitrate / more negative $\mathrm{N}^{*}$ waters of the lower latitudes (stars in Figures $1 \mathrm{~b}$ and $1 \mathrm{c}$ ). Measurements of $\delta^{15} \mathrm{~N}$ of $\mathrm{NO}_{3}^{-}$from the Chilean Margin (black triangles in Figure 1 [De Pol-Holz et al., 2009]) also appear to fall on the two end-member mixing trend between SAMW and the equatorial Pacific in a plot of $\delta^{15} \mathrm{~N}$ of $\mathrm{NO}_{3}^{-}$versus $\mathrm{N}^{*}$ (Figure $6 \mathrm{~d}$ ).

[31] When $\left[\mathrm{NO}_{3}^{-}\right]$is plotted versus $\delta^{15} \mathrm{~N}$ of $\mathrm{NO}_{3}^{-}$ (Figure 6c), some Chilean Margin nitrate measurements fall to the left of the mixing line (resulting from nitrate-loss during active denitrification), but most are to the right and downward of the mixing line. This trend is the expected effect of the accumulation of regenerated nitrate at depth-a process that could substantially increase $\left[\mathrm{NO}_{3}^{-}\right]$while having a weak effect on $\delta^{15} \mathrm{~N}$ of $\mathrm{NO}_{3}^{-}$and $\mathrm{N}^{*}$. Assuming SAMW is the ultimate source of low latitude surface ocean nitrate, the addition of regenerated nutrients increases the original (SAMW) nitrate concentration by $\approx 30 \%$, with an unknown effect on the $\delta^{15} \mathrm{~N}$ of $\mathrm{NO}_{3}^{-}$. With the above assumptions on remineralization, the near-complete consumption of nitrate in the surface layer leads to a correspondence between the $\delta^{15} \mathrm{~N}$ of $\mathrm{NO}_{3}^{-}$brought into the tropical surface and that of the $\mathrm{N}$ sinking out of the surface ocean [Sigman et al., 2000].

[32] Upwelling along the eastern margins and the equator brings nutrient-bearing water to the surface. These nutrients are eventually consumed from the upwelled water, and are transferred back to the shallow interior via remineralization. This process is frequently described as "nutrient trapping" [Najjar et al., 1992]. While this equatorial/tropical nutrient trapping is certainly important, there are other mechanisms for concentrating nutrients in SAMW. In particular, in the eastern South Pacific, nutrient bearing surface water from the Southern Ocean impinges equatorward, transported by the South Pacific subtropical gyre (Figure 1c). These surface nutrients are consumed along the South American coast, combining with the coastal upwelling to drive high productivity. The conversion of these eastern South Pacific surface waters from nutrient-rich to nutrient-poor represents a second source of regenerated nutrient to the underlying SAMWderived waters. In any case, while it is apparent that nutrients have already accumulated to substantial levels in the SEC, it is not yet possible to attribute relative importance to these distinct mechanisms of accumulating nutrients in Pacific mid-depth waters: it could result either through mixing with tropical mid-depth waters that have abundant trapped nutrients or through the addition of regenerated nutrients in the temperate South Pacific, or both.

[33] This question aside, the pathway these modified high latitude intermediate waters take to the equatorial Pacific is likely within the SEC/subtropical gyre to the western boundary [Tsuchiya and Talley, 1996], where there are two main routes to the equator: north of the New Ireland/Solomon Islands [Butt and Lindstrom, 1994] and slightly toward the west, off the Papua New Guinea coast [Tsuchiya et al., 1989; Cravatte et al., 2011]. While the SEC feeds both of these equatorward flows (see arrows in Figure 1b) and they are similarly saline, water on the New Ireland pathway is from 
the lower latitude SEC and has higher nutrients and lower oxygen [Tsuchiya et al., 1989]. Using the nutrient data of Tsuchiya et al. [1989], we calculate a slight difference in $\mathrm{N}^{*}$ between these water masses as well (more negative off New Ireland from the lower latitude SEC flow), which suggests the lower latitude SEC water taking the New Ireland pathway is more influenced by mixing with the ETSP ODZ. The nutrient and dissolved oxygen differences between these two equatorward pathways of intermediate-depth SEC waters is intriguing and suggests that not all SAMW-derived waters approaching the equator are equally modified by the process we have highlighted above. Alternations in the strength of these separate equatorward flows may play a role in equatorial Pacific nitrate variability. Regardless of the pathway to the equator, we find that much of the nitrate characteristics of the SAMW-derived waters can be established in the Southern Hemisphere by interacting with the ETSP ODZ.

\subsection{Source of Equatorial Pacific Thermocline Waters}

[34] The $\delta^{15} \mathrm{~N}$ of $\mathrm{NO}_{3}^{-}$in the equatorial Pacific thermocline $(\approx 100$ to $150 \mathrm{~m}$ depth, Table 1$)$ is not statistically different from that in the deeper "EqPac(SAMW)" (Table 1). This similarity exists despite different histories for each water mass; the equatorial thermocline is ventilated by both the South and North Pacific STMW [Tsuchiya et al., 1989; Fine et al., 1987] and is warmer and more saline, with higher $\left[\mathrm{O}_{2}\right]$ and lower $\mathrm{NO}_{3}^{-}$concentrations than the deeper, SAMWderived waters (Table 1). For SAMW to deliver $\mathrm{NO}_{3}^{-}$to the lower latitude thermocline, there must be diapycnal mixing between the essentially nutrient-deplete STMW and the deeper SAMW-derived waters (as has also been suggested by Toggweiler et al. [1991]). This diapycnal mixing would increase $\mathrm{STMW} \mathrm{NO}_{3}^{-}$concentrations and give these waters a $\delta^{15} \mathrm{~N}$ of $\mathrm{NO}_{3}^{-}$equal to the deeper SAMW. Recent work suggests that substantial STMW modification occurs via diapycnal mixing in the Solomon Sea [Melet et al., 2011]. Mixing with STMW also explains the observed warming and increased salinity of EqPac(SAMW) relative to preformed SAMW (Figure S2). Further, a similar process likely applies in the North Pacific, where subtropical gyre waters also show elevated $\delta^{15} \mathrm{~N}$ of $\mathrm{NO}_{3}^{-}$in the shallow subsurface (Figure 4d).

[35] Equatorial Pacific thermocline waters take a similar western boundary pathway as the SAMW-depth waters described above. However, there is also a North Pacific source to the equatorial thermocline near the western boundary [Fine et al., 1994] along with contributions from both hemispheres in the central and eastern equatorial Pacific via the lower branch of the "Sub Tropical Cell" (STC: white dashed arrows toward the equator in Figure 1) [Fine et al., 1994; Johnson and McPhaden, 1999] (the upper branch of the cell is the upwelled equatorial water). That the equatorial thermocline waters are relatively homogenous despite this variety of sources suggests that the lower branch of the STC consists of waters with similar nitrate characteristics from north and south of the equator.

\subsection{Downward Propagation of the Isotopic Signal by Sinking Organic Matter}

[36] Equatorial upwelling delivers $\mathrm{NO}_{3}^{-}$with elevated $\delta^{15} \mathrm{~N}$ of $\mathrm{NO}_{3}^{-}$from the EUC to the surface, where organic matter with similarly elevated $\delta^{15} \mathrm{~N}$ is produced. The $\mathrm{NO}_{3}^{-}$ upwelled along the equator is transported meridionally as a part of the upper branch of the STC [Johnson, 2001] and this surface $\mathrm{NO}_{3}^{-}$is completely consumed within a few degrees of the equator. While the $\delta^{15} \mathrm{~N}$ of organic matter produced in these $\mathrm{NO}_{3}^{-}$-replete waters will be lower than the upwelled $\delta^{15} \mathrm{~N}$ of $\mathrm{NO}_{3}^{-}$[Altabet and Francois, 1994], the meridionally integrated $\delta^{15} \mathrm{~N}$ of this organic matter will carry the elevated $\delta^{15} \mathrm{~N}$ of the EUC to deeper waters. The remineralization of this organic matter at depth introduces elevated $\delta^{15} \mathrm{~N}$ of $\mathrm{NO}_{3}^{-}$throughout the water column, including deeper waters $(>600 \mathrm{~m})$. The properties of deeper equatorial waters supports this interpretation, considering that AAIW in the equatorial zone has higher $\delta^{15} \mathrm{~N}_{\text {of }} \mathrm{NO}_{3}^{-}$, higher $\left[\mathrm{NO}_{3}^{-}\right]$, and lower $\left[\mathrm{O}_{2}\right]$ than the source waters defined in the Subantarctic Zone (Tables 1 and 2). This sinking flux of high- $\delta^{15} \mathrm{~N}$ PN also partially explains the elevation of $\delta^{15} \mathrm{~N}$ of $\mathrm{NO}_{3}^{-}$in $\approx 3000 \mathrm{~m}$ depth water in the equatorial Pacific relative to deep waters upstream in the circulation of Pacific Deep Water (see Sigman et al. [2009] for a similar explanation for the deep North Pacific). In summary, through diapycnal mixing and the downward flux of high $\delta^{15} \mathrm{~N}$ of organic matter, the elevation of $\delta^{15} \mathrm{~N}$ of $\mathrm{NO}_{3}^{-}$in the intermediate depths of the South Pacific (the depths impacted by processes in the Subantarctic and ETSP ODZ) can also result in an increase of $\delta^{15} \mathrm{~N}$ of $\mathrm{NO}_{3}^{-}$throughout the equatorial Pacific water column.

\subsection{Zonal Exchange by the Deep Tropical Gyres}

[37] Another important feature of equatorial Pacific $\delta^{15} \mathrm{~N}$ of $\mathrm{NO}_{3}^{-}$distribution is the lateral homogeneity for the depth interval between $\approx 100 \mathrm{~m}$ (the EUC) and $600 \mathrm{~m}$. The standard deviation of the measurements is $\pm 0.3 \%$ in the shallowest depths and $\pm 0.1 \%$ in the depths of SAMW-derived waters (see Table 1). This homogeneity is surprising because a zonal gradient in $\delta^{15} \mathrm{~N}$ of $\mathrm{NO}_{3}^{-}$might be expected related to the distance from the eastern tropical Pacific ODZs (where much higher $\delta^{15} \mathrm{~N}$ of $\mathrm{NO}_{3}^{-}$is found; Figures 2 and 4). That there is no such basin-wide gradient suggests that equatorial waters are an ODZ source [Johnson and McPhaden, 1999; Kessler, 2006].

[38] This homogeneity in the $\delta^{15} \mathrm{~N}$ of $\mathrm{NO}_{3}^{-}$is likely maintained by the intensive zonal mixing occurring just below the EUC and between the NSCC and SSCC known as the "Deep Tropical Gyres" [Rowe et al., 2000]. The NSCC and SSCC are subsurface eastward jets that retroflect equatorward in the east and add to the westward flowing Equatorial Intermediate Current and the North and South Equatorial Currents [Gouriou and Toole, 1993; Johnson and Moore, 1997; Rowe et al., 2000; Sloyan et al., 2003]. This circulatory pattern results in significant mixing and homogenization of water located between the NSCC and SSCC, which is the most likely explanation for the subsurface homogeneity in $\delta^{15} \mathrm{~N}$ of $\mathrm{NO}_{3}^{-}$and also $\left[\mathrm{NO}_{3}^{-}\right]$ (not shown), temperature, and salinity (a.k.a. the "Thermostad" [Lukas, 1986]). The homogeneity at even deeper intermediate water depths strongly suggests the presence of an even "deeper" tropical gyre consisting of the Equatorial Intermediate Current and the off-equatorial Intermediate Counter Currents [Firing et al., 1998; Stramma et al., 2010]. 


\subsection{Evidence for Eastward Transport of Newly Fixed N}

[39] So far, we have described processes that work to produce elevated $\delta^{15} \mathrm{~N}$ of $\mathrm{NO}_{3}^{-}$in most of the subtropics and tropics for both the North and South Pacific. However, the relatively low $\delta^{15} \mathrm{~N}$ of $\mathrm{NO}_{3}^{-}$, averaging $(5.5 \pm 0.3) \%$, associated with the high-velocity off-equatorial Southern Subsurface Counter Current (SSCC) (Figures 2 and 4) must have a different origin. Deep Southern Ocean waters have similar $\delta^{15} \mathrm{~N}$ of $\mathrm{NO}_{3}^{-}$, but these colder, denser, deeper, and higher $\left[\mathrm{NO}_{3}^{-}\right]$waters are an unlikely source of the tropical subsurface (Tables 1 and 2). The lower-than-expected $\delta^{15} \mathrm{~N}$ suggests the influence of $\mathrm{N}_{2}$ fixation, which produces organic matter with $\delta^{15} \mathrm{~N} \approx-1 \%$. While there have been suggestions of $\mathrm{N}_{2}$ fixation in the eastern tropical Pacific [Deutsch et al., 2007; Westberry and Siegel, 2006], there is no reason to expect remineralization of newly fixed $\mathrm{N}$ so clearly organized by latitude and depth within the eastern SSCC. Furthermore, strong vorticity barriers poleward of the SSCC make it unlikely that lower $\delta^{15} \mathrm{~N}$ of $\mathrm{NO}_{3}^{-}$is introduced via the subtropical gyre [Johnson and Moore, 1997; Tsuchiya, 1981]. Instead, we propose that the lower $\delta^{15} \mathrm{~N}_{\text {of }} \mathrm{NO}_{3}^{-}$in the SSCC derives from $\mathrm{N}$ fixation prevalent in the western South Pacific where the SSCC has its origins [Dupouy et al., 1988; Campbell et al., 2005; Masotti et al., 2007; Garcia et al., 2007; Biegala and Raimbault, 2008; Raimbault and Garcia, 2008; Bonnet et al., 2009; Law et al., 2011].

[40] Prior work has assumed the EUC and SSCC source waters were the same [Tsuchiya, 1981], but our measurements propose distinct sources for each current. This was also suggested by Butt and Lindstrom [1994] who found an eastward subsurface current beginning around $2^{\circ} \mathrm{S}, 153^{\circ} \mathrm{E}$. Future measurements in the eastern and western tropical Pacific should be able to determine whether this signal is omnipresent in the SSCC and if the lower $\delta^{15} \mathrm{~N}$ of $\mathrm{NO}_{3}^{-}$ signal has temporal variability. Such variability may also explain why $\mathrm{N}^{*}$ (not measured concurrently with $\delta^{15} \mathrm{~N}$ of $\mathrm{NO}_{3}^{-}$) appears to show no clear elevation in the SSCC (Figure 5), as might be expected in regions of $\mathrm{N}_{2}$ fixation [Gruber and Sarmiento, 1997].

[41] It is worth noting that the eastward moving SSCC jet identified by ADCP contains nearly all the low $\delta^{15} \mathrm{~N}_{\text {of }} \mathrm{NO}_{3}^{-}$ along $95^{\circ} \mathrm{W}$, but only part of the lowest $\delta^{15} \mathrm{~N}_{\text {of }} \mathrm{NO}_{3}^{-}$along $110^{\circ} \mathrm{W}$ (Figure 5). There are two possible explanations for this incongruence. First, in the east, some portion of SSCC water moves equatorward and is entrained in the westward moving currents as part of the "deep tropical gyre" [Rowe et al., 2000]. Second, the distribution of tropical Pacific nutrients depends on the integrated transport of the preceding month [Strutton et al., 2008], which may not be perfectly represented in ADCP measurements at the time of sample collection. For example, tropical instability waves may shift water masses meridionally on the scale of days.

[42] In contrast to the SSCC, the NSCC has a North Pacific source [Johnson et al., 2002] and nearly the same $\delta^{15} \mathrm{~N}$ of $\mathrm{NO}_{3}^{-}$as other tropical Pacific subsurface waters (Table 1). Assuming this subsurface jet is not altered en route from the western equatorial Pacific (as with the SSCC), the elevated $\delta^{15} \mathrm{~N}$ of $\mathrm{NO}_{3}^{-}$points to the influence of eastern tropical Pacific denitrification in the eastern tropical North Pacific, perhaps carried to that region by the northern SEC or NEC.
Regardless of their different sources, the SSCC and NSCC play a part in zonally mixing tropical Pacific waters through the actions of the deep tropical gyre.

\subsection{Explanation for Lower $\delta^{15} \mathrm{~N}$ of $\mathrm{NO}_{3}^{-}$Above the Pacific ODZs}

[43] The vigor of lateral transport and exchange in the tropical Pacific may also explain the relatively lower $\delta^{15} \mathrm{~N}$ of $\mathrm{NO}_{3}^{-}$above the very high $\delta^{15} \mathrm{~N}_{\text {of }} \mathrm{NO}_{3}^{-}$in the ODZ core (Figure $2 \mathrm{~b}$ ). It has been argued that this vertical gradient in $\delta^{15} \mathrm{~N}$ of $\mathrm{NO}_{3}^{-}$results from the remineralization of organic matter produced through $\mathrm{N}$ fixation in surface waters above the ODZ [Brandes et al., 1998]. This explanation assumes that $\mathrm{NO}_{3}^{-}$in waters above the ODZ is supplied from the ODZ and therefore starts with an elevated $\delta^{15} \mathrm{~N}$ of $\mathrm{NO}_{3}^{-}(>15 \%)$. In this hypothesis, the elevated $\delta^{15} \mathrm{~N}_{\text {of }} \mathrm{NO}_{3}^{-}$is then reduced to relatively "low" values $(\approx 7 \%$ o) by the remineralized products of $\mathrm{N}$ fixation. However, with a more expansive data set, it is apparent that the typical $\delta^{15} \mathrm{~N}_{\text {of }} \mathrm{NO}_{3}^{-}$for tropical Pacific water $(\approx 7 \%$ ) is very similar to what was previously assumed to be anomalously low values. Therefore, the vertical gradient in $\delta^{15} \mathrm{~N}$ of $\mathrm{NO}_{3}^{-}$above the ODZ could be explained simply by lateral mixing of this typical tropical water. In fact, the waters that are mixing above the ODZs may come directly from the poleward retroflection of the subsurface counter currents [Tsuchiya, 1981], such as the NSCC, which has "a persistent northern component" in the east [Rowe et al., 2000]. It remains to be seen whether this explanation for lower $\delta^{15} \mathrm{~N}$ of $\mathrm{NO}_{3}^{-}$and $\left[\mathrm{NO}_{3}^{-}\right]$is also applicable to similar observations from the Arabian Sea ODZ [Brandes et al., 1998]. The equatorward edges of the ETNP and ETSP ODZs also have large gradients in $\delta^{15} \mathrm{~N}$ of $\mathrm{NO}_{3}^{-}$, $\left[\mathrm{NO}_{3}^{-}\right]$, and $\left[\mathrm{O}_{2}\right]$, especially in the 100 to $300 \mathrm{~m}$ depth range (Figures 4 and 5). Like the waters above the ODZs, these strong lateral gradients may be maintained by the vigorous subsurface flow of the SSCC/NSCC and the retroflection of the Deep Tropical Gyres, which circulates the outward mixing characteristics of ODZ water across the entire Pacific and thus dilutes them locally.

\section{Conclusions}

[44] From the lower thermocline $(\approx 100 \mathrm{~m})$ down to $600 \mathrm{~m}$ in the equatorial Pacific, the $\delta^{15} \mathrm{~N}$ of $\mathrm{NO}_{3}^{-}$is $7.1 \%$, an elevation of more than 2\%o relative to similar depths in North Atlantic and the Antarctic [Sigman et al., 2000; Knapp et al., 2005, 2008; DiFiore et al., 2006]. Coupled with the negative $\mathrm{N}^{*}$ found throughout the Pacific basin, these measurements strongly suggest that denitrification in the eastern tropical Pacific influences nutrient characteristics of the equatorial Pacific waters. In the face of strong meridional gradients in $\delta^{15} \mathrm{~N}$ of $\mathrm{NO}_{3}^{-}$in the eastern Pacific, the zonal homogeneity of the $\delta^{15} \mathrm{~N}$ of $\mathrm{NO}_{3}^{-}$argues that the Deep Tropical Gyres and other deeper zonal mixing processes rapidly exchange $\mathrm{NO}_{3}^{-}$ between east and west Pacific. The depth homogeneity of $\delta^{15} \mathrm{~N}$ of $\mathrm{NO}_{3}^{-}$implicates (i) diapycnal mixing in the upward transport of $\mathrm{NO}_{3}^{-}$from mid-depths to the equatorial undercurrent (EUC) and (ii) the sinking of high $\delta^{15} \mathrm{~N}$ organic $\mathrm{N}$ into the deep ocean.

[45] These conclusions have implications for the nutrient pathway from the deep Southern Ocean to the equatorial Pacific surface waters via Subantarctic Mode Waters 
[Toggweiler et al., 1991; Sarmiento et al., 2004; Palter et al., 2010]. In particular, while deep-sea nutrients are required to replenish the low latitude thermocline, if the pathway is primarily within SAMW, its nutrient characteristics are strongly modified en route to the equatorial Pacific. We identify two processes that, working together, can shape SAMW into subsurface equatorial Pacific water: (1) circulation- and mixing-driven exchange with water influenced by eastern tropical Pacific denitrification and (2) the addition of $\mathrm{NO}_{3}^{-}$ through remineralization of organic matter (i.e., "nutrient trapping"). We propose that much of the mixing occurs on the Chilean margin, a suggestion that is supported by measurements in the region (Figure 6). The regenerated $\mathrm{NO}_{3}^{-}$ added to the equatorial Pacific intermediate-depth water has a $\delta^{15} \mathrm{~N}$ similar to SAMW and the equatorial Pacific; this is consistent with the complete consumption of upwelled $\mathrm{NO}_{3}^{-}$ in tropical waters, leading to sinking $\mathrm{N}$ that is similar in $\delta^{15} \mathrm{~N}$ to the upwelled $\mathrm{NO}_{3}^{-}$. Subtropical South Pacific $\mathrm{NO}_{3}^{-}$(water that is "upstream" of the equatorial Pacific) shows that much of the biogeochemical modification of SAMW has occurred before this water reaches the equator.

[46] In the eastern tropical Pacific, we find the expected elevation of $\delta^{15} \mathrm{~N}$ of $\mathrm{NO}_{3}^{-}$in the Oxygen Deficient Zones $(>18 \%$ in very low oxygen waters), but we also find surprisingly low $\delta^{15} \mathrm{~N}$ of $\mathrm{NO}_{3}^{-}(5.5 \pm 0.3) \%$ being advected eastward within the Southern Subsurface Counter Current. We propose that the low $\delta^{15} \mathrm{~N}_{\text {of }} \mathrm{NO}_{3}^{-}$in the SSCC is derived from the remineralized products of $\mathrm{N}$ fixation in the North Tasman Sea, Coral Sea, and/or the south Pacific gyre. Because of these $\delta^{15} \mathrm{~N}$ of $\mathrm{NO}_{3}^{-}$differences in the eastern tropical Pacific, the meridional exchange between these water masses caused by the Deep Tropical Gyre retroflection can be clearly observed (Figures 4 and 5). Along these lines, we suggest that the lower $\delta^{15} \mathrm{~N}$ of $\mathrm{NO}_{3}^{-}$found at the shallowest depths of the ODZs $(\approx 7 \%$ o compared to $>14 \%$ in the ETNP ODZ core) is due at least in part to the lateral exchange with tropical Pacific waters outside of the ODZs.

[47] While we have described a pathway for Southern Ocean waters to the equatorial Pacific thermocline, there are several predictions we can also make regarding the ultimate fate of this water. For example, the EUC slows east of $95^{\circ} \mathrm{W}$ [Lukas, 1986], where it appears to split around the Galapagos [Karnauskas et al., 2010] and approach the South American coastline, perhaps entering the Peru-Chile Undercurrent where it can influence the ODZ upwelling waters off Peru. The off-equatorial Northern and Southern Subsurface Counter Currents likely feed the Costa Rica Dome and Peru Margin upwelling respectively [Kessler, 2006]. These subsurface counter currents may also be the principle source of lateral ventilation for the ETNP and ETSP oxygen deficient zones [Kessler, 2006; Stramma et al., 2010], making these water masses important with regard to the strength of denitrification.

[48] While the application of $\delta^{15} \mathrm{~N}$ of $\mathrm{NO}_{3}^{-}$measurements has primarily been targeted toward understanding biogeochemical cycling, our study employs $\delta^{15} \mathrm{~N}$ of $\mathrm{NO}_{3}^{-}$as a tool in the study of ocean circulation. For example, we have identified key modifications of Subantarctic waters en route to the equatorial Pacific. Through our dense sampling of eastern equatorial waters, we have also shown that SSCC source waters are different than the other subsurface jets (the EUC and NSCC; see Figure 4). These results highlight the need for a more extensive application of this geochemical tool not only as a tracer for the cycling of nutrients, but also to investigate ocean circulation.

[49] Acknowledgments. We thank the National Oceanic and Atmospheric Administration (NOAA), the crews of the Ka'imimoana and Ronald H. Brown, Mike McPhaden, Brian Lake, Chris Beaverson, Shawn Gendron, and Tonya Watson. Invaluable laboratory help was provided by Greg Cane, Dennis Graham, Yi Wang, and Julien Foriel. Several figures were prepared using Ocean Data View (R. Schlitzer, Ocean Data View, 2011, http://odv.awi.de). We also thank two anonymous reviewers and the Editor for their comments. The measurements at Princeton were supported by the US NSF through grant OCE- 0447570 .

\section{References}

Altabet, M. A., and R. Francois (1994), Sedimentary nitrogen isotopic ratio as a recorder for surface ocean nitrate utilization, Global Biogeochem. Cycles, 8, 103-116, doi:10.1029/93GB03396.

Anderson, L. A. (1995), On the hydrogen and oxygen content of marine phytoplankton, Deep Sea Res., Part I, 42, 1675-1680, doi:10.1016/ 0967-0637(95)00072-E

Biegala, I. C., and P. Raimbault (2008), High abundance of diazotrophic picocyanobacteria $(<3 \mu \mathrm{m})$ in a Southwest Pacific coral lagoon, Aquat. Microb. Ecol., 51, 45-53, doi:10.3354/ame01185.

Bonnet, S., I. C. Biegala, P. Dutrieux, L. O. Slemons, and D. G. Capone (2009), Nitrogen fixation in the western equatorial Pacific: Rates, diazotrophic cyanobacterial size class distribution, and biogeochemical significance, Global Biogeochem. Cycles, 23, GB3012, doi:10.1029/ 2008GB003439.

Bostock, H. C., B. N. Opdyke, and M. J. M. Williams (2010), Characterising the intermediate depth waters of the Pacific Ocean using $\delta^{13} \mathrm{C}$ and other geochemical tracers, Deep Sea Res., Part I, 57(7), 847-859, doi:10.1016/j.dsr.2010.04.005.

Braman, R. S., and S. A. Hendrix (1989), Nanogram nitrite and nitrate determination in environmental and biological materials by V(III) reduction with chemiluminescence detection, Anal. Chem., 61, 2715-2718, doi:10.1021/ac00199a007.

Brandes, J. A., and A. H. Devol (1997), Isotopic fractionation of oxygen and nitrogen in coastal marine sediments, Geochim. Cosmochim. Acta, 61, 1793-1801, doi:10.1016/S0016-7037(97)00041-0.

Brandes, J. A., and A. H. Devol (2002), A global marine-fixed nitrogen isotopic budget: Implications for Holocene nitrogen cycling, Global Biogeochem. Cycles, 16(4), 1120, doi:10.1029/2001GB001856.

Brandes, J. A., A. H. Devol, T. Yoshinari, A. Jayakumar, and S. W. A. Naqvi (1998), Isotopic composition of nitrate in the central Arabian Sea and eastern tropical North Pacific: A tracer for mixing and nitrogen cycles, Limnol. Oceanogr., 43, 1680-1689, doi:10.4319/lo.1998.43.7. 1680

Butt, J., and E. Lindstrom (1994), Currents off the east coast of New Ireland, Papua New Guinea, and their relevance to regional undercurrents in the western equatorial Pacific Ocean, J. Geophys. Res., 99(C6), 12,503-12,514, doi:10.1029/94JC00399.

Campbell, L., E. J. Carpenter, J. P. Montoya, A. B. Kustka, and D. G. Capone (2005), Picoplankton community structure within and outside a Trichodesmium bloom in the southwestern Pacific Ocean, Vie Milieu, $55,185-195$.

Casciotti, K. L., and M. R. McIlvin (2007), Isotopic analyses of nitrate and nitrite from reference mixtures and application to eastern tropical North Pacific waters, Mar. Chem., 107, 184-201, doi:10.1016/j.marchem. 2007.06.021.

Casciotti, K. L., D. M. Sigman, M. G. Hastings, J. K. Bohlke, and A. Hilkert (2002), Measurement of the oxygen isotopic composition of nitrate in seawater and freshwater using the denitrifier method, Anal. Chem., 74, 4905-4912, doi:10.1021/ac020113w.

Casciotti, K. L., T. W. Trull, D. M. Glover, and D. Davies (2008), Constraints on nitrogen cycling at the subtropical North Pacific Station ALOHA from isotopic measurements of nitrate and particulate nitrogen, Deep Sea Res., Part II, 55(14-15), 1661-1672, doi:10.1016/j.dsr2. 2008.04.017.

Cline, J. D., and I. R. Kaplan (1975), Isotopic fractionation of dissolved nitrate during denitrification in the eastern tropical North Pacific Ocean, Mar. Chem., 3, 271-299, doi:10.1016/0304-4203(75)90009-2.

Codispoti, L. A., and J. P. Christensen (1985), Nitrification, denitrification and nitrous oxide cycling in the eastern tropical South Pacific Ocean, Mar. Chem., 16, 277-300, doi:10.1016/0304-4203(85)90051-9.

Codispoti, L. A., and T. T. Packard (1980), Denitrification rates in the eastern tropical South Pacific, J. Mar. Res., 38, 453-477. 
Codispoti, L. A., and F. A. Richards (1976), An analysis of the horizontal regime of denitrification in the eastern tropical North Pacific, Limnol. Oceanogr., 21, 379-388, doi:10.4319/lo.1976.21.3.0379.

Cravatte, S., A. Ganachaud, Q. P. Duong, W. S. Kessler, G. Eldin, and P. Dutrieux (2011), Observed circulation in the Solomon Sea from SADCP data, Prog. Oceanogr., 88(1-4), 116-130, doi:10.1016/j.pocean.2010.12. 015 .

De Pol-Holz, R., R. S. Robinson, D. Hebbeln, D. M. Sigman, and O. Ullo (2009), Controls on sedimentary nitrogen isotopes along the Chile margin, Deep Sea Res., Part II, 56, 1042-1054, doi:10.1016/j.dsr2.2008.09. 014 .

Deutsch, C., N. Gruber, R. M. Key, J. L. Sarmiento, and A. Ganaschaud (2001), Denitrification and $\mathrm{N}_{2}$ fixation in the Pacific Ocean, Global Biogeochem. Cycles, 15(2), 483-506, doi:10.1029/2000GB001291 DOI:dx.doi.org.

Deutsch, C., J. L. Sarmiento, D. M. Sigman, N. Gruber, and J. P. Dunne (2007), Spatial coupling of nitrogen inputs and losses in the ocean, Nature, 445, 163-167, doi:10.1038/nature05392.

Devol, A. H., and J. P. Christensen (1993), Benthic fluxes and nitrogen cycling in sediments of the continental margin of the eastern North Pacific, J Mar Res., 51, 345-372, doi:10.1357/0022240933223765.

DiFiore, P. J., D. M. Sigman, T. W. Trull, M. J. Lourey, K. Karsh, G. Cane, and R. Ho (2006), Nitrogen isotope constraints on subantarctic biogeochemistry, J. Geophys. Res., 111, C08016, doi:10.1029/2005JC003216.

DiFiore, P. J., D. M. Sigman, and R. B. Dunbar (2009), Upper ocean nitrogen fluxes in the Polar Antarctic Zone: Constraints from the nitrogen and oxygen isotopes of nitrate, Geochem. Geophys. Geosyst., 10, Q11016, doi:10.1029/2009GC002468.

Dupouy, C., M. Petit, and Y. Dandonneau (1988), Satellite detected cyanobacteria bloom in the southwestern tropical Pacific - Implication for oceanic nitrogen-fixation, Int. J. Remote Sens., 9, 389-396, doi:10.1080/ 01431168808954862.

Farrell, J. W., T. F. Pedersen, S. E. Calvert, and B. Nielsen (1995), Glacialinterglacial changes in nutrient utilization in the equatorial Pacific Ocean, Nature, 377, 514-517, doi:10.1038/377514a0.

Fine, R. A., W. H. Peterson, and H. G. Ostlund (1987), The penetration of tritium into the tropical Pacific, J. Phys. Oceanogr., 17(5), 553-564, doi:10.1175/1520-0485(1987)017<0553:TPOTIT>2.0.CO;2.

Fine, R. A., R. Lukas, F. M. Bingham, M. J. Warner, and R. H. Gammon (1994), The western equatorial Pacific: A water mass crossroads, J. Geophys. Res., 99, 25,063-25,080, doi:10.1029/94JC02277.

Firing, E., R. Lukas, J. Sadler, and K. Wyrtki (1983), Equatorial undercurrent disappears during 1982-83 El Niño, Science, 222, 1121-1123, doi:10.1126/science.222.4628.1121.

Firing, E., S. E. Wijffels, and P. Hacker (1998), Equatorial subthermocline currents across the Pacific, J. Geophys. Res., 103(C10), 21,413-21,423, doi:10.1029/98JC01944

Ganeshram, R. S., T. F. Pedersen, S. E. Calvert, and J. W. Murray (1995), Large changes in oceanic nutrient inventories from glacial to interglacial periods, Nature, 376, 755-758, doi:10.1038/376755a0.

Garcia, H. E., R. A. Locarnini, T. P. Boyer, and J. I. Antonov (2006), World Ocean Atlas 2005, vol. 4, Nutrients (Phosphate, Nitrate, Silicate), NOAA Atlas NESDIS, vol. 64, edited by S. Levitus, 396 pp., NOAA, Silver Spring, Md.

Garcia, N., P. Raimbault, and V. Sandroni (2007), Seasonal nitrogen fixation and primary production in the Southwest Pacific: Nanoplankton diazotrophy and transfer of nitrogen to picoplankton organisms, Mar. Ecol. Prog. Ser., 343, 25-33, doi:10.3354/meps06882.

Gordon, A. L. (1986), Interocean exchange of thermocline water, J. Geophys. Res., 91(C4), 5037-5046, doi:10.1029/JC091iC04p05037.

Gouriou, Y., and J. Toole (1993), Mean circulation of the upper layers of the western equatorial Pacific Ocean, J. Geophys. Res., 98 22,495-22,520, doi:10.1029/93JC02513.

Graham, B. S., D. Grubbs, K. Holland, and B. N. Popp (2007), A rapid ontogenetic shift in the diet of juvenile yellowfin tuna from Hawaii, Mar. Biol. Berlin, 150(4), 647-658, doi:10.1007/s00227-006-0360-y.

Granger, J., and D. M. Sigman (2009), Removal of nitrite with sulfamic acid for nitrate $\mathrm{N}$ and $\mathrm{O}$ isotope analysis with the denitrifier method, Rapid Commun. Mass Spectrom., 23, 3753-3762, doi:10.1002/rcm.4307.

Granger, J., D. M. Sigman, M. G. Prokopenko, M. F. Lehmann, and P. D. Tortell (2006), A method for nitrite removal in nitrate $\mathrm{N}$ and $\mathrm{O}$ isotope analyses, Limnol. Oceanogr. Methods, 4, 205-212, doi:10.4319/lom. 2006.4.205.

Gruber, N., and J. L. Sarmiento (1997), Global patterns of marine nitrogen fixation and denitrification, Global Biogeochem. Cycles, 11, 235-266, doi:10.1029/97GB00077.

Gu, D. F., and S. G. H. Philander (1997), Interdecadal climate fluctuations that depend on exchanges between the tropics and extratropics, Science, 275, 805-807, doi:10.1126/science.275.5301.805.
Hanawa, K., and L. D. Talley (2001), Mode waters, in Ocean Circulation and Climate, Int. Geophys. Ser., vol. 77, edited by G. Siedler, J. Church, and J. Gould, pp. 373-386, Academic, San Diego, Calif.

Herraiz-Borreguero, L., and S. R. Rintoul (2011), Subantarctic mode water: Distribution and circulation, Ocean Dyn., 61, 103-126, doi:10.1007/ s10236-010-0352-9

Johnson, G. C. (2001), The Pacific Ocean subtropical cell surface limb, Geophys. Res. Lett., 28(9), 1771-1774, doi:10.1029/2000GL012723.

Johnson, G. C., and M. J. McPhaden (1999), Interior pycnocline flow from the subtropical to the equatorial Pacific Ocean, J. Phys. Oceanogr., 29 , 3073-3089, doi:10.1175/1520-0485(1999)029<3073:IPFFTS $>2.0 . C O ; 2$.

Johnson, G. C., and K. E. McTaggart (2010), Equatorial Pacific $13^{\circ} \mathrm{C}$ water eddies in the eastern subtropical South Pacific Ocean, J. Phys. Oceanogr. 40, 226-236, doi:10.1175/2009JPO4287.1.

Johnson, G. C., and D. W. Moore (1997), The Pacific subsurface countercurrents and an inertial model, J. Phys. Oceanogr., 27, 2448-2459, doi:10.1175/1520-0485(1997)027<2448:TPSCAA>2.0.CO;2.

Johnson, G. C., B. M. Sloyan, W. S. Kessler, and K. E. McTaggart (2002), Direct measurements of upper ocean current and water properties across the tropical Pacific during the 1990s, Prog. Oceanogr., 52, 31-61, doi:10.1016/S0079-6611(02)00021-6.

Karnauskas, K. B., R. Murtugudde, and A. J. Busalacchi (2010), Observing the Galápagos-EUC interaction: Insights and challenges, J. Phys. Oceanogr., 40(12), 2768-2777, doi:10.1175/2010JPO4461.1.

Kessler, W. S. (2006), The circulation of the eastern tropical Pacific: A review, Prog. Oceanogr., 69, 181-217, doi:10.1016/j.pocean.2006.03. 009

Knapp, A. N., D. M. Sigman, and F. Lipschultz (2005), N isotopic composition of dissolved organic nitrogen and nitrate at the Bermuda Atlantic Time-series Study site, Global Biogeochem. Cycles, 19, GB1018, doi:10.1029/2004GB002320.

Knapp, A. N., P. J. DiFiore, C. Deutsch, D. M. Sigman, and F. Lipschultz (2008), Nitrate isotopic composition between Bermuda and Puerto Rico: Implication for $\mathrm{N}_{2}$ fixation in the Atlantic Ocean, Global Biogeochem. Cycles, 22, GB3014, doi:10.1029/2007GB003107.

Law, C. S., E. M. S. Woodward, M. J. Ellwood, A. Marriner, S. J. Bury, and K. A. Safi (2011), Response of surface nutrient inventories and nitrogen fixation to a tropical cyclone in the southwest Pacific, Limnol. Oceanogr., 56(4), 1372-1385.

Lehmann, M. F., D. M. Sigman, D. C. McCorkle, B. G. Brunelle, S. Hoffmann, M. Kienast, G. Cane, and J. Clement (2005), Origin of the deep Bering Sea nitrate deficit: Constraints from the nitrogen and oxygen isotopic composition of water column nitrate and benthic nitrate fluxes, Global Biogeochem. Cycles, 19, GB4005, doi:10.1029/ 2005GB002508

Lehmann, M. F., D. M. Sigman, D. C. McCorkle, J. Granger, S. Hoffmann, G. Cane, and B. G. Brunelle (2007), The distribution of nitrate ${ }^{15} \mathrm{~N} /{ }^{14} \mathrm{~N}$ in marine sediments and the impact of benthic nitrogen loss on the isotopic composition of oceanic nitrate, Geochim. Cosmochim. Acta, 71, 5384-5404, doi:10.1016/j.gca.2007.07.025

Liu, K. K. (1979), Geochemistry of inorganic nitrogen compounds in two marine environments: The Santa Barbara Basin and the ocean off Peru, Ph.D. thesis, Univ. of South. Calif., Los Angeles.

Liu, K. K. and I. R. Kaplan (1989), The eastern tropical Pacific as a source of ${ }^{15} \mathrm{~N}$-enriched nitrate in seawater off southern California, Limnol. Oceanogr., 34, 820-830

Lukas, R. (1986), The termination of the equatorial undercurrent in the eastern Pacific, Prog. Oceanogr., 16, 63-90, doi:10.1016/0079-6611(86) 90007-8.

Luyten, J. R., J. Pedlosky, and H. Stommel (1983), The ventilated thermocline, J. Phys. Oceanogr., 13(2), 292-309, doi:10.1175/1520-0485(1983) $013<0292$ :TVT $>2.0 . \mathrm{CO} ; 2$.

Masotti, I., D. Ruiz-Pino, and A. Le Bouteiller (2007), Photosynthetic characteristics of Trichodesmium in the southwest Pacific Ocean: Importance and significance, Mar. Ecol. Prog. Ser., 338, 47-59, doi:10.3354/ meps338047.

McCreary, J. P., and P. Lu (1994), Interaction between the subtropical and equatorial ocean circulations-The subtropical cell, J. Phys. Oceanogr., 24(2), 466-497.

Melet, A., J. Verron, L. Gourdeau, and A. Koch-Larrouy (2011), Equatorward pathways of Solomon Sea water masses and their modifications, J. Phys. Oceanogr., 41(4), 810-826, doi:10.1175/2010JPO4559.1.

Mills, M. M., and K. R. Arrigo (2010), Magnitude of oceanic nitrogen fixation influenced by the nutrient uptake ratio of phytoplankton, Nat. Geosci., 3(6), 412-416, doi:10.1038/ngeo856.

Najjar, R. G., J. L. Sarmiento, and J. R. Toggweiler (1992), Downward transport and fate of organic matter in the ocean: Simulations with a general circulation model, Global Biogeochem. Cycles, 6, 45-76, doi:10.1029/91GB02718. 
Newsome, S. D., P. L. Koch, M. A. Etnier, and D. Aurioles-Gamboa (2006), Using carbon and nitrogen isotope values to investigate maternal strategies in northeast Pacific otariids, Mar. Mammal Sci., 22, 556-572, doi:10.1111/j.1748-7692.2006.00043.x.

Palter, J. B., J. L. Sarmiento, A. Gnanadesikan, J. Simeon, and R. D. Slater (2010), Fueling export production: Nutrient return pathways from the deep ocean and their dependence on the Meridional Overturning Circulation, Biogeosciences, 7(11), 3549-3568, doi:10.5194/bg-7-3549-2010.

Raimbault, P., and N. Garcia (2008), Evidence for efficient regenerated production and dinitrogen fixation in nitrogen-deficient waters of the South Pacific Ocean: Impact on new and export production estimates, Biogeosciences, 5, 323-338, doi:10.5194/bg-5-323-2008.

Redfield, A. C. (1958), The biological control of chemical factors in the environment, Am. Sci., 46, 205-221.

Reid, J. L. (1997), On the total geostrophic circulation of the Pacific Ocean: Flow patterns, tracers, and transports, Prog. Oceanogr., 39(4), 263-352.

Ridgway, K. R., and J. R. Dunn (2007), Observational evidence for a Southern Hemisphere oceanic supergyre, Geophys. Res. Lett., 34, L13612, doi:10.1029/2007GL030392.

Robinson, R. S., P. Martinez, L. D. Pena, and I. Cacho (2009), Nitrogen isotopic evidence for deglacial changes in nutrient supply in the eastern equatorial Pacific, Paleoceanography, 24, PA4213, doi:10.1029/ 2008PA001702.

Rowe, G. D., E. Firing, and G. C. Johnson (2000), Pacific equatorial subsurface countercurrent velocity, transport, and potential vorticity, J. Phys. Oceanogr., 30, 1172-1187, doi:10.1175/1520-0485(2000)030<1172: PESCVT $>2.0 . \mathrm{CO} ; 2$

Sarmiento, J. L., N. Gruber, M. A. Brzezinski, and J. P. Dunne (2004), High-latitude control of thermocline nutrients and low latitude biological productivity, Nature, 427, 56-60, doi:10.1038/nature02127.

Sigman, D. M., M. A. Altabet, R. Francois, D. C. McCorkle, and G. Fischer (1999), The $\delta^{15} \mathrm{~N}$ of nitrate in the Southern Ocean: Consumption of nitrate in surface waters, Global Biogeochem. Cycles, 13, 1149-1166, doi:10.1029/1999GB900038.

Sigman, D. M., M. A. Altabet, D. C. McCorkle, R. Francois, and G. Fischer (2000), The $\delta^{15} \mathrm{~N}$ of nitrate in the Southern Ocean: Nitrogen cycling and circulation in the ocean interior, J. Geophys. Res., 105, 19,599-19,614, doi: $10.1029 / 2000 J C 000265$

Sigman, D. M., K. L. Casciotti, M. Andreani, C. Barford, M. Galanter, and J. K. Bohlke (2001), A bacterial method for the nitrogen isotopic analysis of nitrate in seawater and freshwater, Anal. Chem., 73, 4145-4153, doi:10.1021/ac010088e.

Sigman, D. M., R. Robinson, A. N. Knapp, A. van Geen, D. C. McCorkle, J. A. Brandes, and R. C. Thunnell (2003), Distinguishing between water column and sedimentary denitrification in the Santa Barbara Basin using the stable isotopes of nitrate, Geochem. Geophys. Geosyst., 4(5), 1040 doi:10.1029/2002GC000384.

Sigman, D. M., J. Granger, P. J. DiFiore, M. M. Lehmann, R. Ho, G. Cane, and A. van Geen (2005), Coupled nitrogen and oxygen isotope measurements of nitrate along the eastern North Pacific margin, Global Biogeochem. Cycles, 19, GB4022, doi:10.1029/2005GB002458.

Sigman, D. M., P. J. DiFiore, M. P. Hain, C. Deutsch, and D. M. Karl (2009), Sinking organic matter spreads the nitrogen isotope signal of pelagic denitrification in the North Pacific, Geophys. Res. Lett., 36, L08605, doi:10.1029/2008GL035784.

Sloyan, B. M., G. C. Johnson, and W. S. Kessler (2003), The Pacific cold tongue: A pathway for interhemispheric exchange, J. Phys. Oceanogr., 33 , 1027-1043, doi:10.1175/1520-0485(2003)033<1027:TPCTAP $>2.0$. $\mathrm{CO} ; 2$.

Spero, H. J., and D. W. Lea (2002), The cause of carbon isotope minimum events on glacial terminations, Science, 296, 522-525, doi:10.1126/ science. 1069401

Stramma, L., G. C. Johnson, E. Firing, and S. Schmidtko (2010), Eastern Pacific oxygen minimum zones: Supply paths and multidecadal changes, J. Geophys. Res., 115, C09011, doi:10.1029/2009JC005976.

Strutton, P. G., W. Evans, and F. P. Chavez (2008), Equatorial Pacific chemical and biological variability, 1997-2003, Global Biogeochem. Cycles, 22, GB2001, doi:10.1029/2007GB003045.

Toggweiler, J. R., K. Dixon, and W. S. Broecker (1991), The Peru upwelling and the ventilation of the South Pacific thermocline, J. Geophys. Res., 96, 20,467-20,497, doi:10.1029/91JC02063.

Tsuchiya, M. (1981), The origin of the Pacific equatorial 13 degrees water, J. Phys. Oceanogr., 11, 794-812, doi:10.1175/1520-0485(1981) $011<0794$ :TOOTPE $>2.0 . \mathrm{CO} ; 2$.

Tsuchiya, M., and L. D. Talley (1996), Water-property distributions along an eastern Pacific hydrographic section at 135W, J. Mar. Res., 54(3), 541-564, doi:10.1357/0022240963213583.

Tsuchiya, M., R. Lukas, R. A. Fine, E. Firing, and E. Lindstrom (1989), Source waters of the Pacific equatorial undercurrent, Prog. Oceanogr., 23, 101-147, doi:10.1016/0079-6611(89)90012-8.

Voss, M., J. W. Dippner, and J. P. Montoya (2001), Nitrogen isotope patterns in the oxygen-deficient waters of the eastern tropical North Pacific Ocean, Deep Sea Res., Part I, 48, 1905-1921, doi:10.1016/S09670637(00)00110-2.

Westberry, T. K., and D. A. Siegel (2006), Spatial and temporal distribution of Trichodesmium blooms in the world's oceans, Global Biogeochem. Cycles, 20, GB4016, doi:10.1029/2005GB002673.

C. D. Charles, Scripps Institution of Oceanography, University of California, San Diego, 8675 Discovery Way, La Jolla, CA 92093-0220, USA.

G. H. Haug, Geological Institute, Department of Earth Science, Swiss Federal Institute of Technology, NO G 52.2, Sonneggstrasse 5, CH-8092 Zürich, Switzerland

J. Kaiser, School of Environmental Sciences, University of East Anglia, Earlham Road, Norwich NR4 7TJ, UK.

P. A. Rafter and D. M. Sigman, Department of Geosciences, Princeton University, Guyot Hall, Princeton, NJ 08544, USA. (prafter@princeton.edu) 